Article

\title{
Metabolite Profiling of Methanolic Extract of Gardenia jaminoides by LC-MS/MS and GC-MS and Its Anti-Diabetic, and Anti-Oxidant Activities
}

\author{
Kandasamy Saravanakumar ${ }^{1,+} \mathbb{D}$, SeonJu Park ${ }^{2,+} \mathbb{D}$, Anbazhagan Sathiyaseelan ${ }^{1}$, Kil-Nam Kim ${ }^{2} \mathbb{D}$, \\ Su-Hyeon Cho ${ }^{2,3}$, Arokia Vijaya Anand Mariadoss ${ }^{1}$ (D) and Myeong-Hyeon Wang 1,*(D)
}

1 Department of Bio-Health Convergence, Kangwon National University, Chuncheon 24341, Korea; saravana732@kangwon.ac.kr (K.S.); sathiyaseelan.bio@gmail.com (A.S.); mavijaibt@gmail.com (A.V.A.M.)

2 Chuncheon Center, Korea Basic Science Institute (KBSI), Chuncheon 24341, Korea; sjp19@kbsi.re.kr (S.P.); knkim@kbsi.re.kr (K.-N.K.); chosh93@kbsi.re.kr (S.-H.C.)

3 Department of Medical Biomaterials Engineering, College of Biomedical Sciences, Kangwon National University, Chuncheon 24341, Korea

* Correspondence: mhwang@kangwon.ac.kr

+ These authors contributed equally.

\section{check for}

updates

Citation: Saravanakumar, K.; Park, S.; Sathiyaseelan, A.; Kim, K.-N.; Cho, S.-H.; Mariadoss, A.V.A.; Wang, M.-H. Metabolite Profiling of Methanolic Extract of Gardenia jaminoides by LC-MS/MS and GC-MS and Its Anti-Diabetic, and Anti-Oxidant Activities. Pharmaceuticals 2021, 14 , 102. https://doi.org/10.3390/ ph14020102

Academic Editors: Sabina Lachowicz and Jan Oszmianski

Received: 31 December 2020

Accepted: 25 January 2021

Published: 28 January 2021

Publisher's Note: MDPI stays neutral with regard to jurisdictional claims in published maps and institutional affiliations.

Copyright: (c) 2021 by the authors. Licensee MDPI, Basel, Switzerland. This article is an open access article distributed under the terms and conditions of the Creative Commons Attribution (CC BY) license (https:// creativecommons.org/licenses/by/ $4.0 /)$.
Abstract: In this study, the methanolic extract from seeds of Gardenia jasminoides exhibited strong antioxidant and enzyme inhibition activities with less toxicity to NIH3T3 and HepG2 cells at the concentration of $100 \mu \mathrm{g} / \mathrm{mL}$. The antioxidant activities (DPPH and ABTS), $\alpha$-amylase, and $\alpha$-glucosidase inhibition activities were found higher in methanolic extract (MeOH-E) than $\mathrm{H}_{2} \mathrm{O}$ extract. Besides, $9.82 \pm 0.62 \mu \mathrm{g}$ and $6.42 \pm 0.26 \mu \mathrm{g}$ of MeOH-E were equivalent to $1 \mu \mathrm{g}$ ascorbic acid for ABTS and DPPH scavenging, respectively while $9.02 \pm 0.25 \mu \mathrm{g}$ and $6.52 \pm 0.15 \mu \mathrm{g}$ of MeOH-E were equivalent to $1 \mu \mathrm{g}$ of acarbose for inhibition of $\alpha$-amylase and $\alpha$-glucosidase respectively. Moreover, the cell assay revealed that the addition of $\mathrm{MeOH}-\mathrm{E}(12.5 \mu \mathrm{g} / \mathrm{mL})$ increased about $37 \%$ of glucose uptake in insulin resistant (IR) HepG2 as compared to untreated IR HepG2 cells. The LC- MS/MS and GC-MS analysis of MeOH-E revealed a total of 54 compounds including terpenoids, glycosides, fatty acid, phenolic acid derivatives. Among the identified compounds, chlorogenic acid and jasminoside A were found promising for anti-diabetic activity revealed by molecular docking study and these molecules are deserving further purification and molecular analysis.

Keywords: Gardenia jasminoides Ellis; anti-diabetic activity; LC-MS/MS; GC-MS; anti-oxidant

\section{Introduction}

Diabetes mellitus (DM) is a commonly detected chronic disorder causing major mortality worldwide. The progression of diabetes in the global population was reported as $9.3 \%$ by 2019 and projected to increase about $10.2 \%$ by 2030 and $10.9 \%$ by 2045 [1]. Metabolic malfunctions such as high elevation of the blood sugar (glucose) levels, oxidative stress and abnormal protein and lipid metabolism all lead to DM [2]. DM is categorized into two types: insulin-dependent type-1 diabetes (T1DM) and non-insulin-dependent type-2 diabetes (T2DM) [3]. Diabetic patients who are not able to secrete insulin are characterized as T1DM [4], while patients with insulin deficiency or insulin resistance in the human metabolic system, less insulin sensitivity or signaling in the liver, skeletal muscles, and adipose tissue are characterized as T2DM [5,6]. The prolonged diabetic symptoms (hyperglycemia, polyphagia, polydipsia, and insulin resistance) trigger multiple disorders such as cardiovascular diseases, renal failure, coronary artery, neurological complications, premature death, and limb amputation [7,8]. The diabetes incidence is higher in urban areas than in rural areas. Up 50\% of people do not know that they are affected by diabetes [1].

Enzymes such as $\alpha$-amylase and $\alpha$-glucosidase play a vital role in carbohydrate metabolism. $\alpha$-Amylase catalyzes the conversion of starch into glucose, while $\alpha$-glucosidase 
regulates the p53 signaling pathway and the cleavage of glucose from disaccharides $[9,10]$. Therefore, the intake of foods rich in enzyme ( $\alpha$-amylase and $\alpha$-glucosidase) inhibitors can beneficially reduce the risk of T2DM. However, some commercially available enzyme inhibitor show side effects. For example, miglitol, voglibose, and acarbose can induce diarrhea, bowel disruption, abdominal distress, and these drugs are also not recommended to patients with gastrointestinal disorders [11]. Therefore, isolation of new $\alpha$-amylase and $\alpha$-glucosidase inhibitors from natural resources with less adverse effects can be considered as an alternative to existing enzyme inhibitors. $\alpha$-Amylase and $\alpha$-glucosidase inhibitors can be virtually screened using the molecular docking methods. That way an active imine derivative has been reported for the inhibition of these enzymes by targeting the human lysosomal acid- $\alpha$-glucosidase (PDB: $5 N N 8$ ) and human pancreatic $\alpha$-amylase (PDB: 5E0F) [12].

Worldwide about $80 \%$ of people use herbal medicines to cure various diseases [13]. Herbal medicines have also received attention in diabetes healthcare. The investigation and isolation of novel compounds from indigenous herbal plants to cure diseases can expand the economic value of the traditional herbal industry. G. jasminoides is a shrub belonging to the Rubiaceae family and its metabolites have been proved to possess a variety of ethnopharmacological properties [14]. Traditionally G. jasminoides has been used as folk medicine, as a functional food and a food colorant in Asian countries [15]. The pigments produced from the ripe fruits of this plant have been used as a natural food colorant. The metabolites of G. jasminoides is used as a traditional natural medicine as a diuretic and to cure hemostasis, hypotension (low blood pressure) and to increase blood circulation [14]. Moreover, the pigments are not only used as a food colorant but also applied as beneficial health-promoting agents [16]. The compounds from G. jasminoides display promising pharmacological activities that are reviewed in earlier literature [14,17]. For instance, genipin, geniposide, crocin and crocetin isolated from G. jasminoides possess antidepressant, antidiabetes, antioxidant and antihypertensive activities [18-21], which has prompted additional studies to screen and identify metabolites active against T2DM. Therefore, the present study was aimed at investigating the metabolite profile of MeOH-E of G. jasminoides by LC-MS/MS, GC-MS and screen its anti-diabetic, and anti-oxidant effects using in vitro cytotoxicity, antioxidant, and enzyme inhibitory assays.

\section{Results and Discussion}

\subsection{Yield, Total Phenol and Total Flavonoids Contents}

The yield of different solvent extracts of seed powder of G. jasminoides was found to be $2.45 \%(w / w)$ and $1.58 \%(w / w)$ for methanol extract (MeOH-E) and water extract $\left(\mathrm{H}_{2} \mathrm{O}-\mathrm{E}\right)$, respectively (Table 1). The total phenol and flavonoids are major constituents in secondary metabolites of the plant extracts and they play a vital role in the biological properties of plants [22]. The bioactivities of the plant extracts are strongly correlated with the content of total flavonoids and phenolic substances. The G. jasminoides-derived pigments are shown to have anti-inflammatory, antioxidant, antibacterial activities with bio-health promoting properties by preventing various disorders [14]. Therefore, the content of total phenol (TPC) and total flavonoids (TFC) in $\mathrm{MeOH}-\mathrm{E}$ and $\mathrm{H}_{2} \mathrm{O}-\mathrm{E}$ was determined and the results are expressed as tannic acid equivalents (TAEs) for TPC while the TFC is presented as quercetin equivalents (QEs). For TPC, $769.47 \pm 3.74 \mu \mathrm{g}$ and $632.15 \pm 1.25 \mu \mathrm{g}$ of tannic acid equivalents to one gram of MeOH-E and $\mathrm{H}_{2} \mathrm{O}-\mathrm{E}$, where the TFC $487.54 \pm 1.19 \mu \mathrm{g}$ and $347.00 \pm 2.49 \mu \mathrm{g}$ of quercetin equivalents to one gram of MeOH-E and $\mathrm{H}_{2} \mathrm{O}-\mathrm{E}$, respectively (Table 1 ). 
Table 1. Total Yield, Total Phenol, and Total Flavonoids Contents in Water (H2O-E) and Methanol Extracts (MeOH-E) of Seed Powder of the G. jasminoides Ellis.

\begin{tabular}{cccc}
\hline Samples & Yield of the Extract (\%) & $\begin{array}{c}\text { Total Phenol ( } \mu \text { g of } \\
\text { TAE/g of Extract) }\end{array}$ & $\begin{array}{c}\text { Total Flavonoids ( } \mu \text { g of } \\
\text { QE/g of Extract }\end{array}$ \\
\hline $\mathrm{MeOH}-\mathrm{E}$ & $2.45^{\mathrm{b}}$ & $769.47 \pm 3.74^{\mathrm{b}}$ & $487.54 \pm 1.19^{\mathrm{b}}$ \\
$\mathrm{H}_{2} \mathrm{O}-\mathrm{E}$ & $1.58^{\mathrm{a}}$ & $632.15 \pm 1.25^{\mathrm{a}}$ & $347.00 \pm 2.49^{\mathrm{a}}$ \\
\hline
\end{tabular}

MeOH-E: Methanolic extract, $\mathrm{H}_{2} \mathrm{O}-\mathrm{E}$ : Water extract, the results presented mean $\pm \mathrm{SE}$, tannic acid equivalent (TAE), quercetin equivalent $(\mathrm{QE})$. The different superscript values indicated the significance among the type of extracts $(p<0.05)$.

\subsection{Antioxidant Activities}

Oxidative stress is a major primary cause of various health disorders. Therefore, screening of antioxidants from plant extracts can be a prime way to isolate novel compound against various chronic and metabolic disorders. 1,2-Diphenyl-1-picrylhydrazyl (DPPH) is a stable free radical known to have a purple color with a strong absorption peak at $517 \mathrm{~nm}$. Antioxidants can scavenge the DPPH by donating electrons [23]. (2,2'-Azino-bis(3ethylbenzothiazoline-6-sulfonic acid) diammonium salt $\left(\mathrm{ABTS}^{+}\right)$is a commonly used free radical for antioxidant assays. Mixing of ABTS and potassium persulfate produces the free radical form of the $\mathrm{ABTS}^{+}$which can be scavenged by the addition of synthetic or natural antioxidants [23]. The antioxidant activities of the DPPH and $\mathrm{ABTS}^{+}$varied significantly between the $\mathrm{H}_{2} \mathrm{O}-\mathrm{E}$ and $\mathrm{MeOH}-\mathrm{E}(p<0.05)$. Among the samples, the free radical scavenging activity was found higher in $\mathrm{MeOH}-\mathrm{E}$ than $\mathrm{H}_{2} \mathrm{O}-\mathrm{E}$ in a dose-dependent manner. The free radical scavenging activity of these extracts was compared with a standard to obtain the ascorbic acid equivalents (AAEs). The results revealed that $9.82 \pm 0.62 \mu \mathrm{g}$ of $\mathrm{MeOH}-\mathrm{E}$ and $13.20 \pm 1.25 \mu \mathrm{g}$ of $\mathrm{H}_{2} \mathrm{O}$-E were equivalent to $1 \mu \mathrm{g}$ AAEs for ABTS scavenging. It also varied for the DPPH scavenging with the values of $6.42 \pm 0.26 \mu \mathrm{g}$ for $\mathrm{MeOH}-\mathrm{E}$ and $9.22 \pm 0.81 \mu \mathrm{g}$ for $\mathrm{H}_{2} \mathrm{O}-\mathrm{E}$, which were equivalent to $1 \mu \mathrm{g}$ of ascorbic acid (Table 2). Further, the $\mathrm{IC}_{50}$ concentration was found to be $120.5 \pm 1.09 \mu \mathrm{g} / \mathrm{mL}$ and $262.5 \pm 0.18 \mu \mathrm{g} / \mathrm{mL}$ for $\mathrm{MeOH}-\mathrm{E}$ and $\mathrm{H}_{2} \mathrm{O}-\mathrm{E}$, respectively, for the $\mathrm{ABTS}^{+}$radical scavenging (Table 2). In the case of $\mathrm{DPPH}$ radical scavenging, the $\mathrm{IC}_{50}$ was found to be $274.9 \pm 1.42 \mu \mathrm{g} / \mathrm{mL}$ and $573.1 \pm 0.85 \mu \mathrm{g} / \mathrm{mL}$ for MeOH-E and $\mathrm{H}_{2} \mathrm{O}-\mathrm{E}$, respectively (Table 2). Similarly, the methanol extract of $G$. volkensii reportedly shows a moderate DPPH scavenging activity [23]. Moreover, an earlier work reported that the water extract of $G$. jasminoides shows a higher $\mathrm{DPPH}$ and $\mathrm{ABTS}^{+}$scavenging activity than the ethanol extract. It is also observed from earlier study that the water extract of $G$. jasminoides exhibited the $\mathrm{IC}_{50}$ values of 0.14 and $0.21 \mathrm{mg} / \mathrm{mL}$ for DPPH and $\mathrm{ABTS}^{+}$scavenging activities respectively [24]. This result indicates a variation between the present work and earlier work for $\mathrm{IC}_{50}$ of $\mathrm{H}_{2} \mathrm{O}-\mathrm{E}$, probably due to the differences in the extraction method and sample collection location. The present results indicated that the antioxidant activity was higher in $\mathrm{MeOH}-\mathrm{E}$ than that in $\mathrm{H}_{2} \mathrm{O}-\mathrm{E}$ due to a higher total phenolic and flavonoids content [25]. The present work also found a similar relationship between antioxidant activity and total phenol content of $\mathrm{MeOH}-\mathrm{E}$ and $\mathrm{H}_{2} \mathrm{O}-\mathrm{E}$, which is in accordance with earlier works $[23,25]$.

Table 2. Antioxidant and Diabetes-Related Enzyme Inhibitory Activities of Water $\left(\mathrm{H}_{2} \mathrm{O}-\mathrm{E}\right)$ and Methanol Extracts $(\mathrm{MeOH}-\mathrm{E})$ of Seed Powder of the G. jasminoides.

\begin{tabular}{|c|c|c|c|c|c|c|c|c|}
\hline \multirow[b]{2}{*}{ Samples } & \multicolumn{4}{|c|}{ Inhibition Concentration (IC50: $\mu \mathrm{g} \cdot \mathrm{mL}^{-1}$ ) } & \multicolumn{2}{|c|}{ Activity ( $\mu \mathrm{g}$ Extract/ $\mu \mathrm{g}$ AAEs) } & \multicolumn{2}{|c|}{ Activity ( $\mu \mathrm{g}$ Extract/ $\mu \mathrm{g}$ ACEs) } \\
\hline & ABTS Radical & DPPH Radical & $\begin{array}{l}\alpha \text {-Amylase } \\
\text { Inhibition }\end{array}$ & $\begin{array}{l}\alpha \text {-Glucosidase } \\
\text { Inhibition }\end{array}$ & ABTS Radical & DPPH Radical & $\begin{array}{l}\alpha \text {-Amylase } \\
\text { Inhibition }\end{array}$ & $\begin{array}{l}\alpha \text {-Glucosidase } \\
\text { Inhibition }\end{array}$ \\
\hline $\mathrm{MeOH}-\mathrm{E}$ & $120.5 \pm 1.09^{a}$ & $274.9 \pm 1.42^{\mathrm{a}}$ & $432.05 \pm 0.51^{\mathrm{a}}$ & $798.25 \pm 0.84^{\mathrm{a}}$ & $9.82 \pm 0.62$ & $6.42 \pm 0.26$ & $9.02 \pm 0.25$ & $6.52 \pm 0.15$ \\
\hline $\mathrm{H}_{2} \mathrm{O}-\mathrm{E}$ & $262.5 \pm 0.18^{b}$ & $573.1 \pm 0.85^{b}$ & $784.02 \pm 0.88^{b}$ & $1052.23 \pm 1.25^{b}$ & $13.20 \pm 1.25$ & $9.22 \pm 0.81$ & $15.22 \pm 0.55$ & $12.52 \pm 0.61$ \\
\hline
\end{tabular}

MeOH-E: Methanolic extract, $\mathrm{H}_{2} \mathrm{O}$-E: Water extract, the results presented mean \pm SE, the different superscript in values indicated the significance among the type of extracts $(p<0.05)$. IC50 is indicated the concentration required to inhibit the $50 \%$ of free radicals or enzymes. ACEs: Acarbose equivalents, AAEs: ascorbic acid equivalents. 


\subsection{Enzyme Inhibitory Activities}

The enzymes $\alpha$-amylase and $\alpha$-glucosidase are involved in carbohydrate metabolism in the conversion of simple sugars from polysaccharides or disaccharides and also in catalyzing the blood glucose level that results in T2DM hyperglycemia [26]. Therefore, inhibition of these enzymes can control the prevalence of T2DM. Moreover, several studies also reported that screening of these enzyme inhibitors is crucial for the discovery of novel diabetes drugs $[27,28]$. The present work showed the enzyme ( $\alpha$-amylase and $\alpha$-glucosidase) inhibitory activity of $\mathrm{MeOH}-\mathrm{E}$ and $\mathrm{H}_{2} \mathrm{O}$-E of seed powder of G. jasminoides (Table 2). Among the two samples, $\mathrm{MeOH}$-E exhibited higher $\alpha$-amylase and $\alpha$-glucosidase inhibition activities than $\mathrm{H}_{2} \mathrm{O}$-E. The $9.02 \pm 0.25 \mu \mathrm{g}$ of MeOH-E and $15.22 \pm 0.55 \mu \mathrm{g}$ of $\mathrm{H}_{2} \mathrm{O}$-E were equivalent to $1 \mu \mathrm{g}$ of acarbose for $\alpha$-amylase inhibition activity (Table 2 ). In the case of $\alpha$-glucosidase inhibition, $6.52 \pm 0.15 \mu \mathrm{g}$ of MeOH-E and $12.52 \pm 0.61 \mu \mathrm{g}$ of $\mathrm{H}_{2} \mathrm{O}-\mathrm{E}$ were found to equivalent to $1 \mu \mathrm{g}$ of acarbose (Table 2). The IC50 of MeOH-E were found to be $432.05 \pm 0.51 \mu \mathrm{g} / \mathrm{mL}$ and $798.25 \pm 0.84 \mu \mathrm{g} / \mathrm{mL}$ for $\alpha$-amylase and $\alpha$ glucosidase inhibition activity respectively (Table 2). Among the two samples, $\mathrm{MeOH}-\mathrm{E}$ showed promising activities of antioxidant and $\alpha$-amylase and $\alpha$-glucosidase inhibition. Therefore, MeOH-E was selected further for cell culture experiments.

\subsection{Cytotoxicity}

The cytotoxic effects of MeOH-E in a mouse fibroblast (NIH3T3) cell line was determined using a WST assay. The results revealed that MeOH-E at the concentration of $\leq 12.5 \mu \mathrm{g} / \mathrm{mL}$ did not show any cytotoxicity, while that at $>25-100 \mu \mathrm{g} / \mathrm{mL}$ exhibited moderate cytotoxicity in the NIH3T3 cell line (Figure 1a). Similarly, the extract of G. jasminoides is reportedly non-toxic to the normal human MCF-10A cell line [29]. Another mouse model experiment confirmed that the pigments derived from G. jasminoides are less toxic [30]. Meanwhile, different solvent extracts of G. jasminoides have been reported to have promising cytotoxicity towards various cancer cells, including cervical cancer cell line (HeLa), skin malignancy cell line (A375), human non-small cell lung carcinoma cell line (H1299), and breast cancer cell line (MCF-7) [29,31]. However, to ensure the non-cytotoxicity of the $\mathrm{MeOH}-\mathrm{E}$ in the NIH3T3 cell line the present study applied an acridine orange/ethidium bromide (AO/EB) fluorescent staining assay. This fluorescent method is used to determine the apoptosis-associated changes in cells based on the nucleus damage [32]. The AO/EB staining results indicated no apoptosis cells in the control group, and in the cells treated with $12.5 \mu \mathrm{g} / \mathrm{mL}$; however, early stage apoptosis cells were observed at $50 \mu \mathrm{g} / \mathrm{mL}$ and $100 \mu \mathrm{g} / \mathrm{mL}$ (Figure 1b). Similarly, the early apoptosis in the osteosarcoma cells was detected by $\mathrm{AO} / \mathrm{EB}$ staining as indicated by yellow-green and crescent-shaped cells [32].

(a)

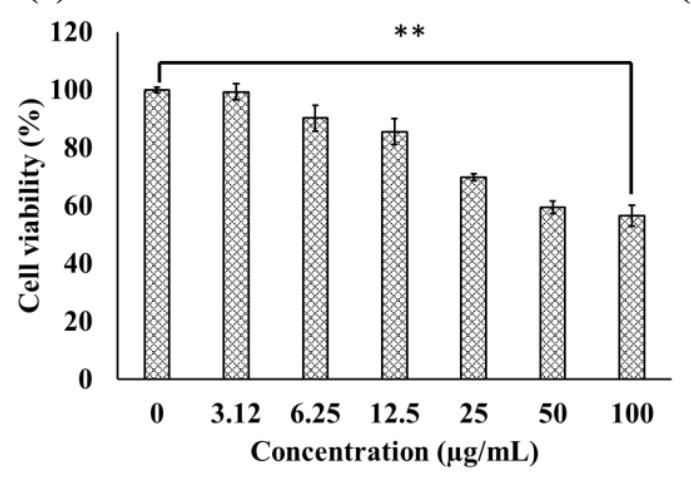

(b)

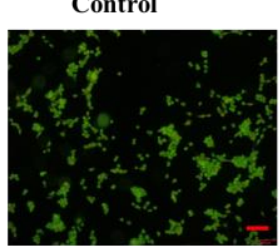

$50 \mu \mathrm{g} / \mathrm{mL}$

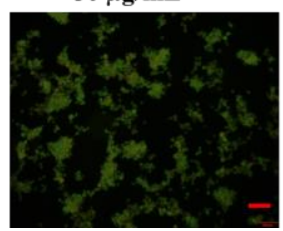

$12.5 \mu \mathrm{g} / \mathrm{mL}$

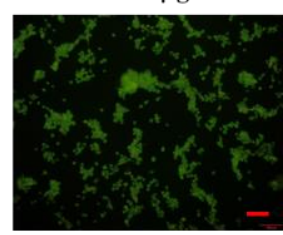

$100 \mu \mathrm{g} / \mathrm{mL}$

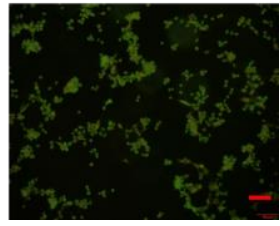

Figure 1. Cytotoxicity of the methanolic extract (MeOH-E) of G. jasminoides in NIH3T3 cell line (a), AO/EB staining assay (b). ** $p<0.01$ significant. Scale bar $100 \mu \mathrm{m}$. 


\subsection{Effect of MeOH-E on Cell Viability and Glucose Uptake in HepG2 Cell Line}

$\mathrm{MeOH}-\mathrm{E}$ did not display significant cytotoxicity on the Hep2 cell line at the concentration of $\leq 25 \mu \mathrm{g} / \mathrm{mL}$ and only at $100 \mu \mathrm{g} / \mathrm{mL}$ was significant cytotoxicity exhibited (Figure 2a). This revealed the non-toxicity of MeOH-E in the HepG2 cell line at $\leq 25 \mu \mathrm{g} / \mathrm{mL}$. Therefore, the effect of $\mathrm{MeOH}-\mathrm{E}$ treatment in the glucose metabolism was tested by glucose uptake assay in non-insulin resistant and insulin resistant (IR)-HepG2 cell lines. The glucose uptake was found to be higher in the non-IR HepG2 cell line than that in the IR-HepG2 cell line. However, the addition of MeOH-E $(12.5 \mu \mathrm{g} / \mathrm{mL})$ increased $\sim 37 \%$ of glucose uptake in IR-HepG2 as compared to untreated IR HepG2 cell line (Figure 2b). This experiment also led to the interesting observation that the treatment above $25 \mu \mathrm{g} / \mathrm{mL}$ of $\mathrm{MeOH}-\mathrm{E}$ to IR-Hep2 cell line significantly decreased the glucose uptake due to toxicity of the extract (Figure 2b). This is in accordance with an earlier report on ethyl acetate extract of Physalis alkekengi in glucose uptake in HepG2 cells [33]. The present work revealed that the treatment of $12.5 \mu \mathrm{g} / \mathrm{mL}$ was optimal for the increased glucose uptake by the IR-HepG2 cell line.

(a)

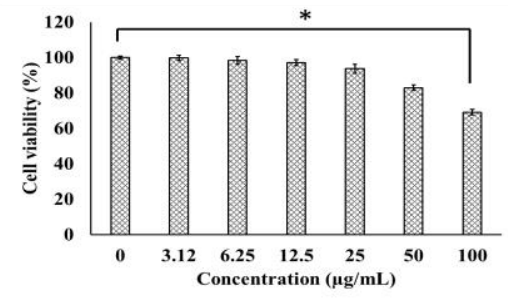

(b)

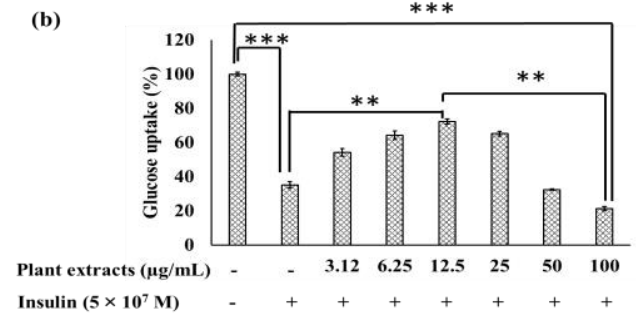

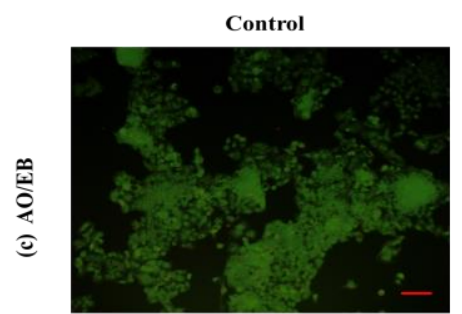

$25 \mu \mathrm{g} / \mathrm{mL}$
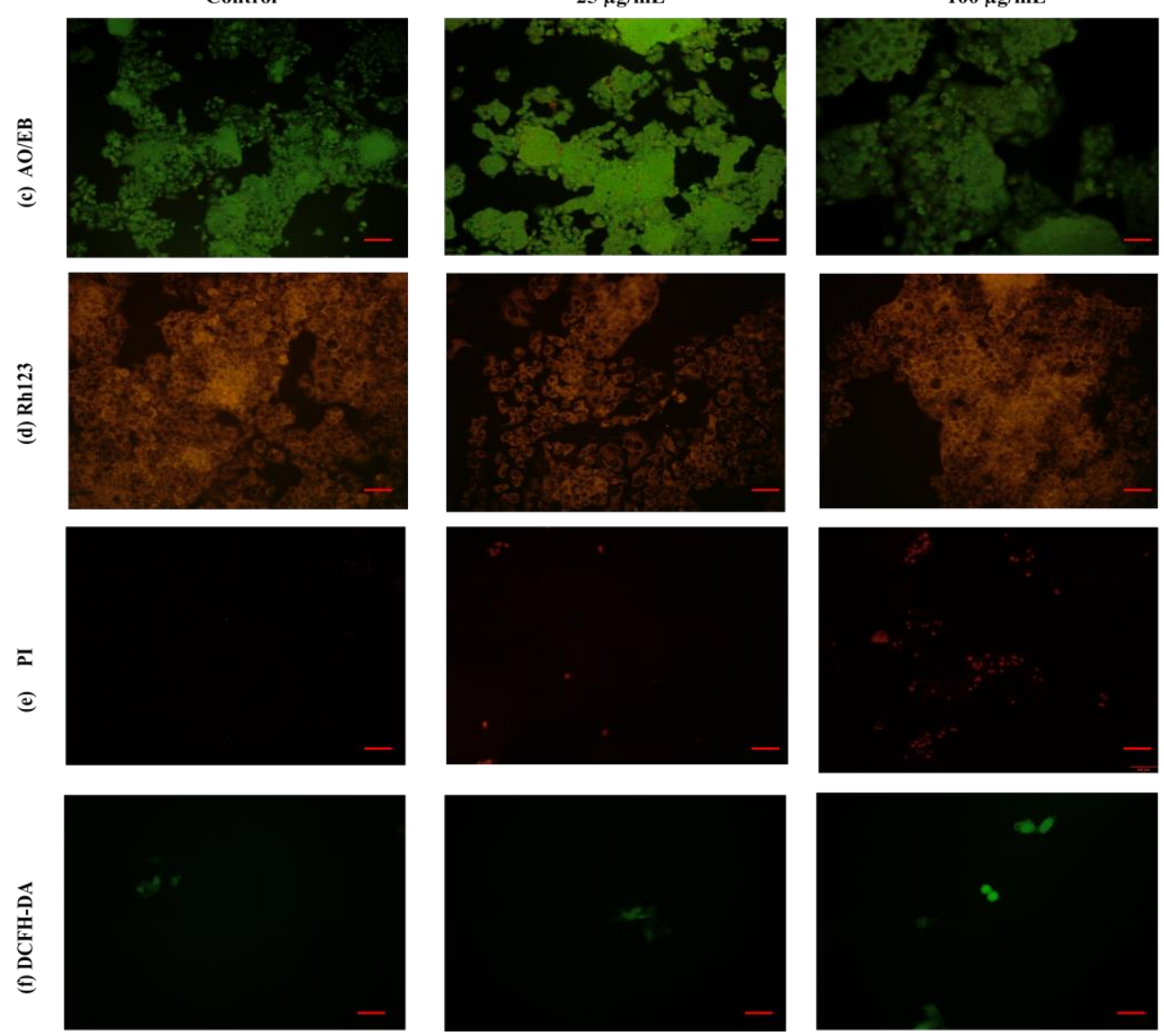

Figure 2. Cytotoxicity of the methanolic extract (MeOH-E) of G. jasminoides in insulin-resistant (IR) HepG2 cell line (a), glucose uptake (b), AO/EB staining assay (c), mitochondrial membrane potential (d), measurement of nucleus damage by PI (e), analysis of the reactive oxygen species generation (f). Scale bar $100 \mu \mathrm{m}$ for C \& E, and $50 \mu \mathrm{m}$ for D \& F. ${ }^{*} p<0.05$, ${ }^{* *} p<0.01,{ }^{* * *} p<0.001$ significant. 


\section{Fluorescent Assay}

The cytotoxicity of MeOH-E in the HepG2 cell line was measured by fluorescent $\mathrm{AO} / \mathrm{EB}$, rhodamine 123 (Rh123), propidium iodide (PI), and $2^{\prime}-7^{\prime}$ dichlorofluorescin diacetate (DCFH-DA) staining assays (Figure 2c-f). The cells were grouped as live cells (light green), apoptosis cells (fluorescent or yellowish, orange), necrosis cells (red) [34]. The MeOH-E at $25 \mu \mathrm{g} / \mathrm{mL}$ and $100 \mu \mathrm{g} / \mathrm{mL}$ ) caused slight cytotoxicity for IR-HepG2 cell line as evident by pyknosis and congregated chromatin emitting green or yellow and some red fluorescence while the untreated control cells emitted uniform green fluorescence (Figure 2c). Rh123 staining is adopted to measure the mitochondrial membrane potential (MMP) loss in the HepG2 cell line. Rh123 dye effectively stains with rich mmP and loss of $\mathrm{mmP}$ is indicated with the decrease of dye emission [35]. Similarly, the present study observed that the Rh123 was highly emitted in the HepG2 cell line treated with different concentrations of $\mathrm{MeOH}-\mathrm{E}$ and it indicated less toxicity of extracts (Figure 2d). The PI is an impaired nucleic acid membrane stain used for the detection of dead cells in a cell population [36,37]. The present study observed no PI-stained cells in the untreated control group while the treatment of $25 \mu \mathrm{g} / \mathrm{mL}$ and $100 \mu \mathrm{g} / \mathrm{mL}$ of $\mathrm{MeOH}-\mathrm{E}$ displayed the dead cells as red-colored (Figure 2e). DCFH-DA staining results indicated that the treatment of $\mathrm{MeOH}-\mathrm{E}(25 \mu \mathrm{g} / \mathrm{mL})$ did not cause the ROS mediated cytotoxicity while it exhibited slight cytotoxicity in the HepG2 cell line (Figure 2f).

\subsection{Metabolite Profiling of the MeOH-E of G. jasminoides}

To identify the components of the MeOH-E of G. jasminoides, we tentatively identified them using two major hyphenated techniques: gas chromatography-mass spectrometry (GC-MS) and liquid chromatography with tandem mass spectrometry (LC-MS/MS), which cover quite different subsets of metabolites. For instance, GC-MS has a preference for volatile metabolites covering primary metabolism including organic and amino acids, sugars, sugar alcohols, and phosphorylated intermediates. In contrast, LC-MS/MS covers mostly polar compounds predominant in secondary metabolites such as phenolics and terpenoids $[38,39]$.

\subsubsection{Tentative Identification of Compounds by LC-MS/MS}

The compounds present in the MeOH-E were tentatively identified using LC-MS/MS and the TIC chromatogram of metabolic profile of the MeOH-E is shown in the Supplementary Figure S1. The LC-MS/MS analysis revealed the presence of 39 phytochemicals that belonging to various subclasses such as phenolic, flavonoids, terpenes, iridoid glycosides, organic acids, and gardenia carotenoids (Table 3). These compounds were identified based on the $m / z$ of molecular ion $[\mathrm{M}-\mathrm{H}]^{-}$and interpretation of the MS and MS/MS spectra comparison with the MassLynx V4.1 library (Waters Corporation, Milford, MA, USA). The compounds were identified using the in-house phytochemical library (UNIFI 1.8; Waters) $[40,41]$ and previously reported literature [14,42]. Structures of the selected compounds are presented in Figure 3. 
Irioids

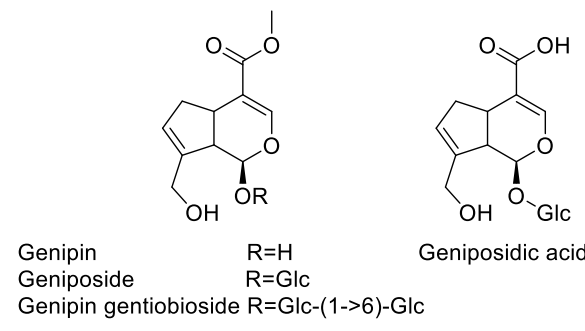

Monoterpenoides

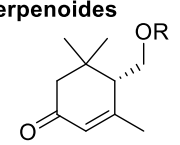

Jasminoside $A$ R=Glc

Jasminoside $H R=G l c-(1->6)-G l c$<smiles>COCC1=CC(=O)CC(C)(C)C1CO</smiles>

Jasminoside B<smiles>COC(=O)C1=COC(CO)C2C(=O)C=CC12O</smiles>

Gardenoside<smiles>COC(=O)C1=COC(O)C2C(O)CC(O)C1C2OC</smiles>

Shanzhiside methyl ester<smiles>COC1C(C)=C(C=O)C(C)(C)CC1O</smiles>

Jasminoside D

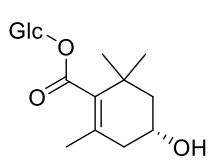

Jasminoside $F$

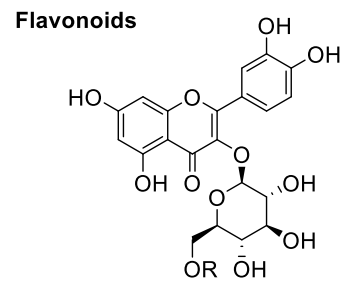

Quercetin-3-O-glucopyranoside $\mathrm{R}=\mathrm{H}$ Rutin

Carotenoids<smiles>[R]OC(=O)/C(C)=C/C=C/C(C)=C/C=C/C=C(C)/C=C/C=C(\C)C(=O)O[R]</smiles>

Organic acids and others

Protocatechuic acid<smiles>COc1cc(CCO)ccc1OC1CCCCC1</smiles>

4-(2-hydroxyethyl)-2-methoxyphenyl glucopyranoside<smiles>O=C(C=Cc1ccc(O)c(O)c1)OC1CC(O)C(O)CC1C(=O)O</smiles>

Chlorogenic acid

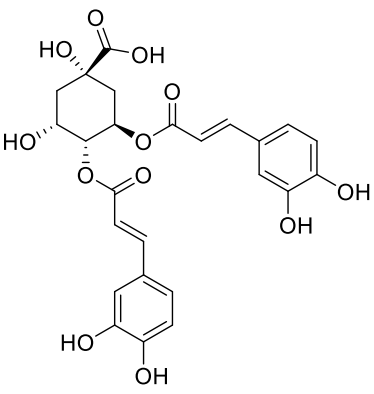

3,4-Dicaffeoyl quinic acid

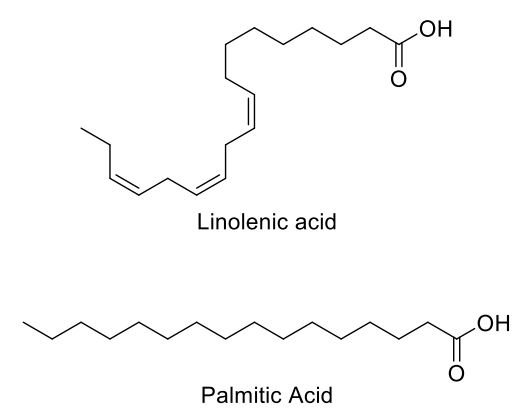

Palmitic Acid

Figure 3. Structures of selected compounds identified by LC-MS/MS.

Iridoids

The iridoid glycosides are a group of phytochemicals that is commonly present in various families of the plant families including Rubaiaceae [43]. According to our LC-MS/MS analysis, MeOH-E of G. jasminoides (Rubiaceae) exhibited compounds such as geniposidic acid $(m / z$ 373.11), shanzhiside methyl ester $(\mathrm{m} / \mathrm{z} 405.14), 6 \beta$-hydroxygeniposide $(\mathrm{m} / \mathrm{z}$ 403.12), gardenoside $(m / z$ 403.12), genipin gentiobioside $(m / z 549.18)$, genipin $(m / z 225.07)$, geniposide $(m / z 387.13)$, coumaroylgenipin gentiobioside $(m / z 695.21)$, and feruloylgenipin gentiobioside $(m / z$ 725.23). Detailed identification information of these compounds such as retention time, formula, observed $m / z$, mass error, response and product ion mass are listed in Table 3.

Table 3. Metabolite Profiling of Methanolic Extract (MeOH-E) of G. jasminoides by LC-MS/MS Analysis.

\begin{tabular}{|c|c|c|c|c|c|c|c|}
\hline Component Name & $\underset{(\mathrm{min})}{\mathrm{RT}}$ & Formula & $\begin{array}{l}\text { Observed } m / z \\
{[\mathbf{M}-\mathbf{H}]^{-}}\end{array}$ & $\begin{array}{l}\text { Mass Error } \\
(\mathrm{ppm})\end{array}$ & Response & MS/MS Fragmentation $(\mathrm{m} / \mathrm{z})$ & References \\
\hline \multicolumn{8}{|l|}{ Iridoids } \\
\hline Geniposidic acid & 1.04 & $\mathrm{C}_{16} \mathrm{H}_{22} \mathrm{O}_{10}$ & 373.1142 & 0.4 & 6013 & 193.0507 & {$[44,45]$} \\
\hline Shanzhiside methyl ester & 1.06 & $\mathrm{C}_{17} \mathrm{H}_{26} \mathrm{O}_{11}$ & 405.1402 & 0.0 & 1994 & $229.0722,391.1251$ & {$[45]$} \\
\hline $6 \beta$-Hydroxygeniposide & 1.43 & $\mathrm{C}_{17} \mathrm{H}_{24} \mathrm{O}_{11}$ & 403.1249 & 1.4 & 273,632 & $205.0511,223.0615,241.0721$ & [46] \\
\hline Gardenoside & 1.69 & $\mathrm{C}_{17} \mathrm{H}_{24} \mathrm{O}_{11}$ & 403.1238 & 0.4 & 1146 & $207.0664,225.0770$ & [45] \\
\hline Genipin gentiobioside & 1.70 & $\mathrm{C}_{23} \mathrm{H}_{34} \mathrm{O}_{15}$ & 549.1828 & 0.4 & 464,390 & $207.0664,225.0770$ & {$[45]$} \\
\hline Genipin & 2.00 & $\mathrm{C}_{11} \mathrm{H}_{14} \mathrm{O}_{5}$ & 225.0770 & 0.2 & 81,760 & $193.0506,207.0664$ & {$[44,46]$} \\
\hline Geniposide & 2.00 & $\mathrm{C}_{17} \mathrm{H}_{24} \mathrm{O}_{10}$ & 387.1300 & 0.5 & $1,952,147$ & $207.0664,225.0770$ & {$[45,46]$} \\
\hline Coumaroylgenipin gentiobioside & 2.81 & $\mathrm{C}_{32} \mathrm{H}_{40} \mathrm{O}_{17}$ & 695.2191 & 0.2 & 301,727 & $225.0768,469.1354$ & {$[45,46]$} \\
\hline Feruloylgenipin gentiobioside & 2.89 & $\mathrm{C}_{33} \mathrm{H}_{42} \mathrm{O}_{18}$ & 725.2300 & 0.2 & 108,903 & $193.0507,225.0768$ & [47] \\
\hline
\end{tabular}


Table 3. Cont.

\begin{tabular}{|c|c|c|c|c|c|c|c|}
\hline Component Name & $\begin{array}{c}\mathrm{RT} \\
(\mathrm{min})\end{array}$ & Formula & $\begin{array}{l}\text { Observed } m / z \\
{[\mathbf{M}-\mathbf{H}]^{-}}\end{array}$ & $\begin{array}{l}\text { Mass Error } \\
(\mathrm{ppm})\end{array}$ & Response & MS/MS Fragmentation $(\mathrm{m} / \mathrm{z}$ ) & References \\
\hline \multicolumn{8}{|l|}{ Monoterpenoides } \\
\hline Jasminoside $\mathrm{F}$ isomers & 1.25 & $\mathrm{C}_{16} \mathrm{H}_{26} \mathrm{O}_{9}$ & 361.1506 & 0.5 & 36,284 & $137.0975,181.0872,199.0973$ & [45] \\
\hline Jasminoside D & 1.47 & $\mathrm{C}_{16} \mathrm{H}_{26} \mathrm{O}_{8}$ & 345.1558 & 1.0 & 171,766 & $165.0922,183.1027$ & [48] \\
\hline Jasminoside B & 1.66 & $\mathrm{C}_{16} \mathrm{H}_{26} \mathrm{O}_{8}$ & 345.1599 & 0.1 & 37,456 & $151.0764,165.0921,169.0870$ & [46] \\
\hline Jasminoside J & 1.66 & $\mathrm{C}_{16} \mathrm{H}_{24} \mathrm{O}_{7}$ & 327.1446 & -1.1 & 2058 & $151.0764,165.0921$ & [49] \\
\hline Jasminodiol & 1.96 & $\mathrm{C}_{10} \mathrm{H}_{16} \mathrm{O}_{3}$ & 183.1029 & 0.2 & 2722 & 135.0817 & [48] \\
\hline Gardenate A & 1.99 & $\mathrm{C}_{12} \mathrm{H}_{18} \mathrm{O}_{6}$ & 257.1033 & 0.3 & 104 & 225.0770 & [50] \\
\hline Picrocrocinic acid & 2.07 & $\mathrm{C}_{16} \mathrm{H}_{26} \mathrm{O}_{8}$ & 345.1554 & -0.1 & 47,270 & 165.0921 & [45] \\
\hline Jasminoside $\mathrm{H}$ & 3.00 & $\mathrm{C}_{22} \mathrm{H}_{36} \mathrm{O}_{12}$ & 491.2123 & -0.3 & 30,153 & $167.1076,323.0976$ & [46] \\
\hline Crocusatin C & 3.64 & $\mathrm{C}_{10} \mathrm{H}_{16} \mathrm{O}_{2}$ & 167.1083 & 0.2 & 260 & 137.0973 & {$[45,46,48]$} \\
\hline Jasminoside A/E & 3.67 & $\mathrm{C}_{16} \mathrm{H}_{26} \mathrm{O}_{7}$ & 329.1606 & 0.1 & 3985 & 167.1079 & [48] \\
\hline $6^{\prime}$-Sinapoyljasminoside C & 3.92 & $\mathrm{C}_{27} \mathrm{H}_{34} \mathrm{O}_{11}$ & 533.2021 & -1.4 & 2024 & $165.0918,205.0507$ & [48] \\
\hline Methyl dihydrojasmonate & 4.36 & $\mathrm{C}_{13} \mathrm{H}_{22} \mathrm{O}_{3}$ & 225.1495 & -0.5 & 241 & 181.1596 & Pubchem \\
\hline 2-Hydroxyethylgardenamide A & 6.69 & $\mathrm{C}_{13} \mathrm{H}_{17} \mathrm{NO}_{5}$ & 266.1039 & 0.5 & 155 & - & Pubchem \\
\hline \multicolumn{8}{|l|}{ Flavonoids } \\
\hline \multirow{2}{*}{$\begin{array}{l}\text { Rutin } \\
\text { Quercetin-3-O- } \beta-D- \\
\text { glucopyranoside }\end{array}$} & 2.28 & $\mathrm{C}_{27} \mathrm{H}_{30} \mathrm{O}_{16}$ & 609.1464 & 0.3 & 16,687 & 300.0278 & [47] \\
\hline & 2.42 & $\mathrm{C}_{21} \mathrm{H}_{20} \mathrm{O}_{12}$ & 463.0884 & 0.2 & 3003 & 300.027 & [47] \\
\hline \multicolumn{8}{|l|}{ Carotenoids } \\
\hline Crocetin & 2.67 & $\mathrm{C}_{20} \mathrm{H}_{24} \mathrm{O}_{4}$ & 327.1589 & -1.3 & 844 & 283.1704 & [51] \\
\hline Crocin A & 3.95 & $\mathrm{C}_{44} \mathrm{H}_{64} \mathrm{O}_{24}$ & 975.3707 & -0.8 & 64,605 & $327.1603,651.2661$ & {$[47,51]$} \\
\hline \multicolumn{8}{|l|}{ Organic acids and others } \\
\hline Quinic acid & 0.81 & $\mathrm{C}_{7} \mathrm{H}_{12} \mathrm{O}_{6}$ & 191.0563 & 1.2 & 85,121 & $137.0242,173.0459$ & [52] \\
\hline Trimethoxy-O-glucopyranoside & 1.08 & $\mathrm{C}_{15} \mathrm{H}_{22} \mathrm{O}_{9}$ & 391.1249 & 0.9 & 54,704 & 167.0716 & Pubchem \\
\hline $\begin{array}{l}\text { 4-(2-Hydroxyethyl)-2- } \\
\text { methoxyphenyl } \\
\beta \text {-D-glucopyranoside }\end{array}$ & 1.37 & $\mathrm{C}_{15} \mathrm{H}_{22} \mathrm{O}_{8}$ & $\begin{array}{l}{[\mathrm{M}+\mathrm{COOH}]^{-}} \\
375.1298\end{array}$ & 0.3 & 2140 & $151.0763,167.0713$ & Pubchem \\
\hline Caffeoylquinic acid & 1.44 & $\mathrm{C}_{16} \mathrm{H}_{18} \mathrm{O}_{9}$ & 353.0876 & -0.5 & 217 & 161.0248 & [45] \\
\hline Protocatechuic acid & 1.51 & $\mathrm{C}_{7} \mathrm{H}_{6} \mathrm{O}_{4}$ & 153.0193 & -0.2 & 11,003 & 109.0294 & {$[45]$} \\
\hline Chlorogenic acid & 1.70 & $\mathrm{C}_{16} \mathrm{H}_{18} \mathrm{O}_{9}$ & 353.0878 & 0.0 & 4552 & $161.0248,191.0562$ & {$[46,48]$} \\
\hline Dicaffeoylquinic acid & 2.79 & $\mathrm{C}_{25} \mathrm{H}_{24} \mathrm{O}_{12}$ & 515.1196 & 0.2 & 6085 & $179.0350,191.0559$ & {$[47]$} \\
\hline Linolenic acid & 10.53 & $\mathrm{C}_{18} \mathrm{H}_{30} \mathrm{O}_{2}$ & 277.2174 & 0.2 & 1586 & - & {$[53,54]$} \\
\hline n-Pentadecanal & 10.74 & $\mathrm{C}_{15} \mathrm{H}_{30} \mathrm{O}$ & 225.2217 & -1.3 & 4866 & - & {$[53]$} \\
\hline Linoleic acid & 11.60 & $\mathrm{C}_{18} \mathrm{H}_{32} \mathrm{O}_{2}$ & 279.233 & 0.2 & 162,838 & - & [54] \\
\hline Acetylursolic acid & 12.71 & $\mathrm{C}_{32} \mathrm{H}_{50} \mathrm{O}_{4}$ & 497.3634 & -0.5 & 3297 & - & Pubchem \\
\hline Palmitic acid & 12.72 & $\mathrm{C}_{16} \mathrm{H}_{32} \mathrm{O}_{2}$ & 255.2331 & 0.6 & 10,687 & - & {$[53,54]$} \\
\hline Ethyl palmitate & 12.96 & $\mathrm{C}_{18} \mathrm{H}_{34} \mathrm{O}_{2}$ & 281.2488 & 0.8 & 38,097 & - & [53] \\
\hline
\end{tabular}

\section{Monoterpenoids}

The monoterpenes, whether linear (acyclic) or containing rings (bicyclic and monocyclic), belons to a class of terpenes that possess remarkable applications in the food and pharmaceutical industries [55]. G. jasminoides was reported to be a rich source of monoterpenoids and a total of 26 monoterpenoids have been reported from G. jasminoides [56-60]. The present study identified a total of 13 monoterpenoids from MeOH-E of G. jasminoides based on the deprotonated molecular ions observed in the LC-MS/MS analysis. The formulas of identified compounds were as follows: $\mathrm{C}_{10} \mathrm{H}_{16} \mathrm{O}_{2}\left(m / z\right.$ 167.1083), $\mathrm{C}_{10} \mathrm{H}_{16} \mathrm{O}_{3}$ (m/z 183.1029), $\mathrm{C}_{12} \mathrm{H}_{18} \mathrm{O}_{6}\left(m / z\right.$ 257.1033), $\mathrm{C}_{13} \mathrm{H}_{17} \mathrm{NO}_{5}(m / z 266.1039), \mathrm{C}_{13} \mathrm{H}_{22} \mathrm{O}_{3}(m / z$ 225.1495), $\mathrm{C}_{16} \mathrm{H}_{24} \mathrm{O}_{7}\left(m / z\right.$ 327.1446), $\mathrm{C}_{16} \mathrm{H}_{26} \mathrm{O}_{7}\left(m / z\right.$ 329.1606), $\mathrm{C}_{16} \mathrm{H}_{26} \mathrm{O}_{8}(m / z$ 345.1599), $\mathrm{C}_{16} \mathrm{H}_{26} \mathrm{O}_{9}\left(m / z\right.$ 361.1506), $\mathrm{C}_{22} \mathrm{H}_{36} \mathrm{O}_{12}\left(\mathrm{~m} / z\right.$ 491.2123) and $\mathrm{C}_{27} \mathrm{H}_{34} \mathrm{O}_{11}(\mathrm{~m} / z$ 533.2021). The compound names, MS/MS fragmentation patterns, retention times as well as response factors corresponding to each chemical are described in Table 3.

\section{Flavonoids}

Flavonoids are a major group of molecules present in the plants with rich bioactivities including antioxidant, anti-diabetes, and anticancer properties. According to the earlier literature, a total of 22 flavonoids has been reported from the various extracts of G. jasminoides [14]. Similarly, the present study had identified compounds such as rutin $\left(\mathrm{C}_{27} \mathrm{H}_{30} \mathrm{O}_{16}\right)$ and quercetin-3-O- $\beta$-D-glucopyranoside $\left(\mathrm{C}_{21} \mathrm{H}_{20} \mathrm{O}_{12}\right)$ with MS/MS fragmentation of quercetin, aglycone of those two previously mentioned compounds, at $m / z 300.0278$

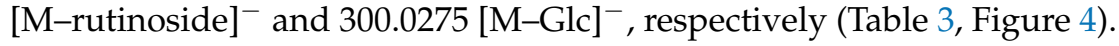



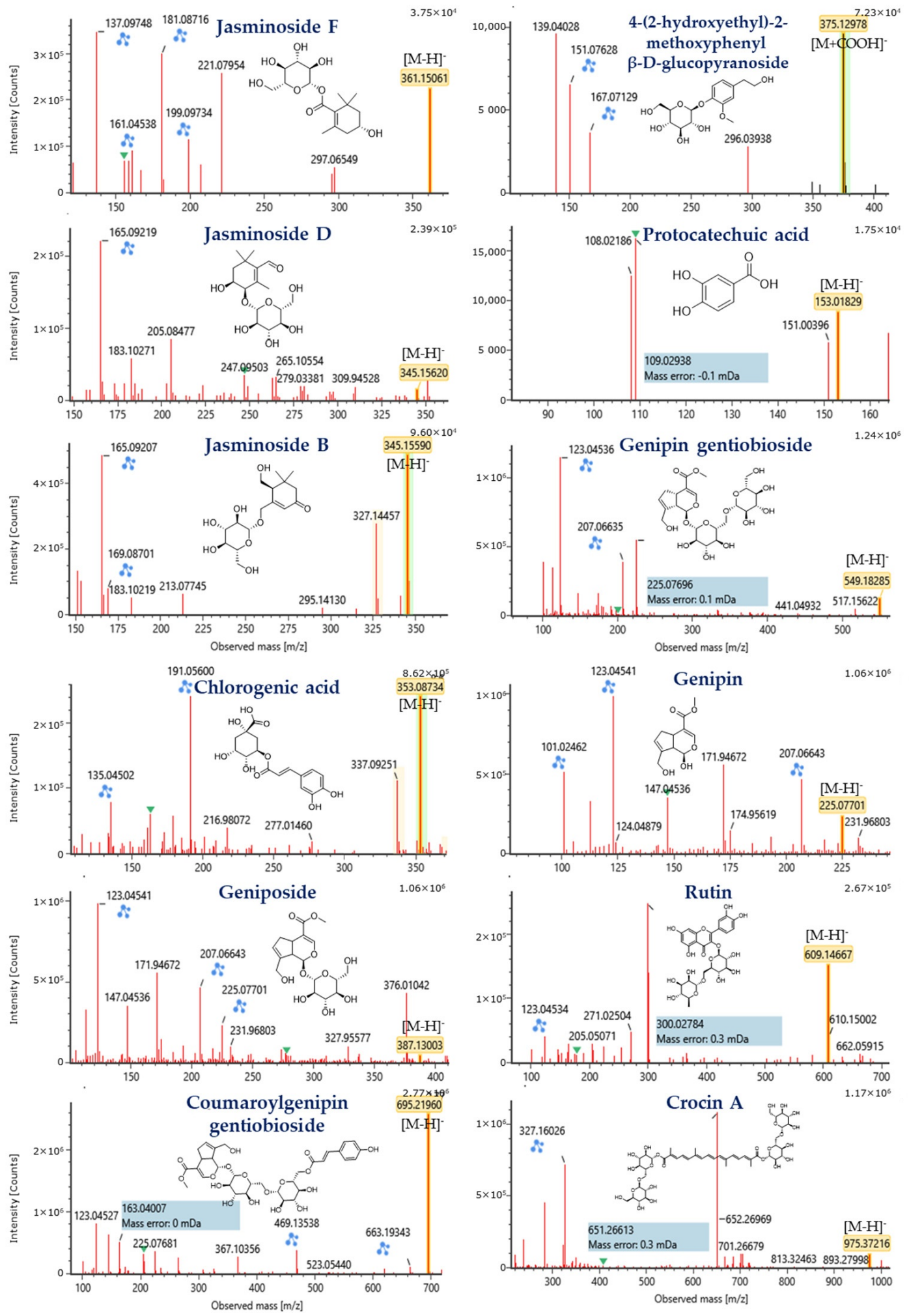

Figure 4. MS/MS spectrum of compounds identified from methanolic extract (MeOH-E) of G. jasminoides by LC-MS/MS analysis. Blue markings and the numbers in blue highlighter indicate the predicted MS/MS fragmentation of the compounds provided by MassFragment, an in silico fragmentation tool that uses a systematic bond disconnection approach to identify possible structures from the parent structure. 


\section{Carotenoids}

The carotenoids are a major constituent of the G. jasminoides, which is composed of carotenoids and similar compounds [61]. These compounds are used as food colorants as well as bioactive food additives. Based on the peaks observed from the LCQTOF MS/MS analysis of MeOH-E, crocetin and crocin A were identified by their corresponding MS/MS fragmentats at $m / z 283.1704[\mathrm{M}-\mathrm{COOH}]^{-}$for crocetin and 651.2661 $\left[\mathrm{M}-\mathrm{H} \text {-gentiobioside }+\mathrm{H}_{2} \mathrm{O}\right]^{-}$and 327.1603 [M-H-gentiobioside $\left.* 2+\mathrm{H}_{2} \mathrm{O} * 2\right]^{-}$for crocin A (Table 3, Figure 4). Similarly, these compounds were reported from the flower and fruit of this plant $[62,63]$.

\section{Organic Acids and Others}

According to the earlier research reports, a total of 30 organic acids with various bioactive properties, including phenolic acids and fatty acids can be isolated from G. jasminoides [14]. Similarly, the present study has identified a total of 13 organic acids and others from $\mathrm{MeOH}-\mathrm{E}$ of G. jasminoides based on LC-MS/MS of deprotonated observed mass and its MS/MS fragmentation. The compounds were identified as chlorogenic acid $\left(\mathrm{C}_{16} \mathrm{H}_{18} \mathrm{O}_{9}\right)$, caffeoylquinic acid $\left(\mathrm{C}_{16} \mathrm{H}_{18} \mathrm{O}_{9}\right)$, dicaffeoylquinic acid $\left(\mathrm{C}_{25} \mathrm{H}_{24} \mathrm{O}_{12}\right)$, protocatechuic acid $\left(\mathrm{C}_{7} \mathrm{H}_{6} \mathrm{O}_{4}\right)$, quinic acid $\left(\mathrm{C}_{7} \mathrm{H}_{12} \mathrm{O}_{6}\right), 2,4,6$-trimethoxy-1-O-glucopyranoside $\left(\mathrm{C}_{15} \mathrm{H}_{22} \mathrm{O}_{9}\right)$, 4-(2-hydroxyethyl)-2methoxyphenyl $\beta$-D-glucopyranoside $\left(\mathrm{C}_{15} \mathrm{H}_{22} \mathrm{O}_{8}\right)$, linolenic acid $\left(\mathrm{C}_{18} \mathrm{H}_{30} \mathrm{O}_{2}\right)$, n-pentadecanal $\left(\mathrm{C}_{15} \mathrm{H}_{30} \mathrm{O}\right)$, linoleic acid $\left(\mathrm{C}_{18} \mathrm{H}_{32} \mathrm{O}_{2}\right)$, acetylursolic acid $\left(\mathrm{C}_{32} \mathrm{H}_{50} \mathrm{O}_{4}\right)$, palmitic acid $\left(\mathrm{C}_{16} \mathrm{H}_{32} \mathrm{O}_{2}\right)$, and ethyl palmitate $\left(\mathrm{C}_{18} \mathrm{H}_{34} \mathrm{O}_{2}\right)$. Further detailed identification information is shown in Table 3.

\subsubsection{Tentative Identification of the Compounds by GC-MS}

GC-MS analysis evidenced the presence of fifteen volatile compounds classified into organic acids and their derivatives including fatty acids and phenolic acids in $\mathrm{MeOH}-\mathrm{E}$ of G. jasminoides based on the electronic library, W8N05ST.L (Supplementary Table S1). The major compounds were found to be $(9 Z, 12 Z)$-octadeca-9,12-dienoic acid $(69.43 \%)$, hexadecanoic acid $(16.09 \%)$, octadecanoic acid $(8.32 \%)$, thymine $(0.22 \%)$, 3,5-dihydroxy6-methyl-2,3-dihydro-4H-pyran-4-one (0.26\%), 3-carene (0.89\%), 2-methylphenoxyacetic acid $(0.49 \%)$, 2-amino-3-hydroxybenzoic acid $(0.43 \%), 2,6$-dimethyl-3-(methoxymethyl)p-benzoquinone $(0.60 \%)$, tetradecanoic acid $(0.08 \%)$, methyl palmitate $(0.20 \%)$, methyl linoleate $(1.07 \%)$, methyl elaidate $(0.55 \%)$, squalene $(0.78 \%)$ and vitamin $\mathrm{E}(0.36 \%)$. Some of these compounds are known for promising antioxidant, antibacterial, and anticancer activities $[64,65]$.

\subsection{In Silico Screening of Enzyme Inhibitors \\ 2.7.1. Protein and Ligand Preparation}

The protein and ligand were prepared according to the methods described earlier [12]. The protein molecular dock preparation was done using the AutoDock vina after the removal of the water molecules. Further, the ligand was selected for the molecular docking study based on Lipinski's drug-likeness rules (Supplementary Table S2). The Lipinski's indicated five rules, which is favor to select a compound as an orally active agent such as (i) the molecular weight of the compounds $<500 \mathrm{Da}$, (ii) hydrogen bond donor $<5$, (iii) hydrogen bond acceptor $<10$, (iv) miLogP $<5$ and molar refractivity (40-130) [66]. Out of 33 unique compounds identified from MeOH-E of G. jasminoides by LC-MS/MS (Figure 3) and GC-MS (Supplementary Figure S2), a total of the 26 compounds were selected for the molecular docking study based on Lipinski's rules satisfactory (Supplementary Table S2).

2.7.2. Molecular Docking

Molecular Interaction with $\alpha$-Amylase

Molecular docking results revealed that all the selected compounds could interact with $\alpha$-amylase. Among the compounds screened, jasminoside F, chlorogenic acid, jasminoside A, and thymine showed a higher docking score against $\alpha$ amylase (Table 4 ; Figure 5). The 
jasminoside $\mathrm{F}$ exhibited the binding affinity score of $-8.5 \mathrm{kcal} / \mathrm{mol}$ with two hydrogen bond interactions with amino acid residues of His 299 and Gln63 in $\alpha$ amylase (Figure 5a). Chlorogenic acid showed the binding affinity score of $-8.7 \mathrm{kcal} / \mathrm{mol}$ by interacting with amino acid residues of Arg421, Gly403, Arg398, Ser289 through six hydrogen bond interactions in $\alpha$ amylase (Figure $5 b$ ). Jasminoside A displayed a strong binding affinity score of $-8.7 \mathrm{kcal} / \mathrm{mol}$ on $\alpha$-amylase through interacting its amino acid residues of Arg195, His299 via two hydrogen bonds (Figure 5c).

Table 4. Molecular Docking Analysis Catalytic Activity of Compounds Identified from the Methanolic Extract (MeOH-E) of G. jasminoides Against Diabetes Related Enzymes of $\alpha$-Amylase and $\alpha$-Glucosidase.

\begin{tabular}{|c|c|c|c|c|c|c|c|}
\hline \multirow[t]{2}{*}{ S.No } & \multirow[t]{2}{*}{ Compound } & \multicolumn{3}{|c|}{$\alpha$-Amylase } & \multicolumn{3}{|c|}{$\alpha$-Glucosidase } \\
\hline & & $\begin{array}{l}\text { No. H } \\
\text { Bonds }\end{array}$ & $\begin{array}{l}\text { H Bond Interacting } \\
\text { Amino Acids }\end{array}$ & $\begin{array}{l}\text { Binding Affinity } \\
\text { (kcal/mol) }\end{array}$ & $\begin{array}{l}\text { No. } \mathrm{H} \\
\text { Bonds }\end{array}$ & $\begin{array}{l}\text { H Bond Interacting } \\
\text { Amino Acids }\end{array}$ & $\underset{(\mathrm{kcal} / \mathrm{mol})}{\text { Binding Affinity }}$ \\
\hline 1 & Quinic acid & 3 & Arg252 & -5.7 & 4 & $\begin{array}{l}\text { His623, Leu761, } \\
\text { Val760, Met269 }\end{array}$ & -6.3 \\
\hline 2 & Jasminoside F & 2 & His $299, \mathrm{Gln} 63$ & -8.5 & 5 & $\begin{array}{l}\text { Thr473, Asn476, } \\
\text { Arg102 }\end{array}$ & -7.8 \\
\hline 3 & $\begin{array}{l}\text { 4-(2-Hydroxyethyl)-2- } \\
\text { methoxyphenyl } \\
\beta \text {-D-glucopyranoside }\end{array}$ & 2 & His299, Lys200 & -6.9 & 2 & Glu759, His490 & -7.3 \\
\hline 4 & Jasminoside D & - & - & 0 & - & - & 0 \\
\hline 5 & Protocatechuic acid & 3 & $\operatorname{Arg} 421, \operatorname{Arg} 398$ & -5.5 & 2 & $\begin{array}{c}\text { Glu654, Ala655 } \\
\text { Arg102, }\end{array}$ & -5.9 \\
\hline 6 & Jasminoside B & 2 & His299, Gln63 & -7.7 & 6 & $\begin{array}{l}\text { Tyr104,Gly241,Arg103, } \\
\text { Asn } 476\end{array}$ & -7.3 \\
\hline 7 & Jasminoside J & - & - & -8.1 & 2 & Glu762, Leu761 & -7.3 \\
\hline 8 & Chlorogenic acid & 6 & $\begin{array}{l}\text { Arg421,Gly403,Arg398, } \\
\text { Ser289 }\end{array}$ & -8.7 & 5 & $\begin{array}{l}\text { Met269, Glu759, } \\
\text { Val760, Tyr266 }\end{array}$ & -8.2 \\
\hline 9 & Genipin & 2 & Arg195, His299 & -6.6 & 1 & Val760 & -6.4 \\
\hline 10 & Crocusatin C & 2 & His305, Gln63 & -5.9 & 3 & $\begin{array}{l}\text { Glu762, Met269, } \\
\text { Leu761 }\end{array}$ & -5.8 \\
\hline 11 & Jasminoside A & 2 & Arg195, His299 & -8.7 & 4 & $\begin{array}{l}\text { Val760, Leu761, } \\
\text { Glu762 }\end{array}$ & -7.8 \\
\hline 12 & Thymine & 6 & $\begin{array}{l}\text { Gly403, Arg398, } \\
\text { Arg421 }\end{array}$ & -5.3 & 3 & $\begin{array}{l}\text { Glu759, Ser757, } \\
\text { Asp753 }\end{array}$ & -5.1 \\
\hline 13 & $\begin{array}{l}\text { 3,5-Dihydroxy-6-methyl-2,3- } \\
\text { dihydro-4H-pyran-4-one }\end{array}$ & 4 & $\begin{array}{l}\text { Ala310, Gly309, } \\
\text { Asn301, Arg346 }\end{array}$ & -5.5 & 4 & $\begin{array}{l}\text { Arg317, Met314, } \\
\text { Asn323 }\end{array}$ & -5.1 \\
\hline 14 & 3-Carene & - & - & -5.5 & - & - & -5.3 \\
\hline 15 & 2-Methylphenoxyacetic acid & 1 & Gln63 & -5.6 & 3 & $\begin{array}{l}\text { Leu761, Val760, } \\
\text { Glu759 }\end{array}$ & -5.7 \\
\hline 16 & 2-Amino-3-hydroxybenzoic acid & 2 & His299, Asp197 & -5.6 & 5 & $\begin{array}{l}\text { Asn323, Leu311, } \\
\text { Met314, Arg317 }\end{array}$ & -5.3 \\
\hline 17 & $\begin{array}{l}\text { 2,6-Dimethyl-3-(methoxy-methyl)- } \\
\text { p-benzoquinone }\end{array}$ & 2 & His185, Ala128 & -5.5 & 2 & Leu761, Met269 & -5.5 \\
\hline 18 & Tetradecanoic acid & - & - & -5.8 & - & - & -5.7 \\
\hline 19 & Methyl palmitate & 2 & His299, Asp197 & -6.1 & 1 & His301 & -6.4 \\
\hline 20 & Hexadecanoic acid & - & -1 & -5.8 & 1 & Glu759 & -6.2 \\
\hline 21 & Methyl linoleate & 1 & Asp197 & -6.5 & 1 & Asn430 & -6.3 \\
\hline 22 & Methyl elaidate & 1 & Asp197 & -6.2 & 1 & Asn430 & -6.2 \\
\hline 23 & (9Z,12Z)-Octadeca-9,12-dienoic acid & 3 & Asn105, Ala106 & -6.3 & 1 & Arg491 & -6.5 \\
\hline 24 & Octadecanoic acid & 2 & Asn105, Ala106 & -6.2 & 1 & His 580 & -6 \\
\hline 25 & Acarbose derived trisaccharide & 11 & $\begin{array}{c}\text { Thr6, Arg10, Gly9, } \\
\text { Gln7, Gly334, Arg421, } \\
\text { Gln404 }\end{array}$ & -8.3 & 8 & $\begin{array}{l}\text { Trp39, Cys40, Ala13, } \\
\text { Pro14, Asp11, Arg237, } \\
\text { Trp179 }\end{array}$ & -8.7 \\
\hline 26 & Acarbose & 3 & His299, gln63, Thr163 & -8.3 & 6 & $\begin{array}{l}\text { Trp39, Cys40, Pro14, } \\
\text { Ala13, Arg237, Asp11 }\end{array}$ & -8.7 \\
\hline
\end{tabular}

The organic compound thymine showed a binding affinity score of $-5.3 \mathrm{kcal} / \mathrm{mol}$ against $\alpha$-amylase by interacting its residues of Gly403, Arg398, Arg421 by six hydrogen bonds (Figure 5d). Moreover, the positive control of the acarbose derived trisaccharide exhibited higher hydrogen bonds of 11 and amino acids (Thr6, Arg10, Gly9, Gln7, Gly334, Arg421, Gln404) interaction with $\alpha$-amylase with binding affinity score of $-8.3 \mathrm{kcal} / \mathrm{mol}$ (Figure 5e) while another control acarbose showed only three hydrogen bonds and amino acids (His299, gln63, Thr163) interactions with binding affinity score of $-8.3 \mathrm{kcal} / \mathrm{mol}$ (Figure 5f). Overall, the results revealed that among the compounds tested, jasminoside $\mathrm{A}$ and chlorogenic acid were found to have the potential to interact with $\alpha$-amylase with high binding affinity score than other molecules including positive controls. Similarly, the compound jasminoside is known for tyrosinase inhibition [56] while the phenolic compound chlorogenic acid exhibits anti-oxidative and anti-diabetic activities $[67,68]$. 


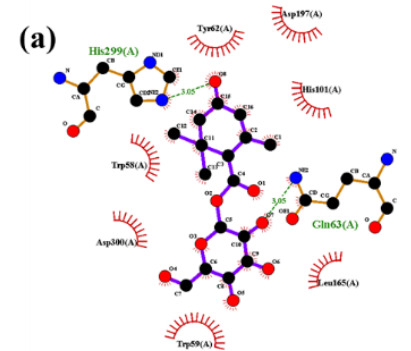

(d)

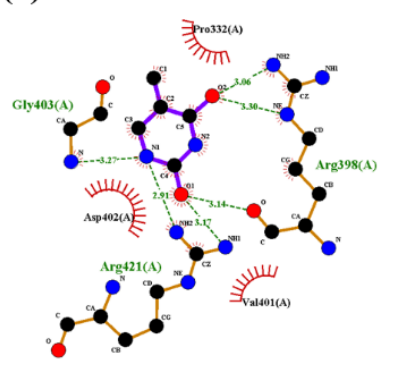

(b)

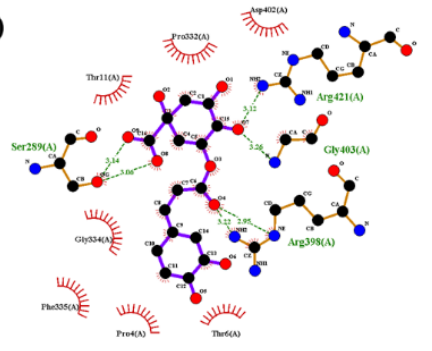

(e)

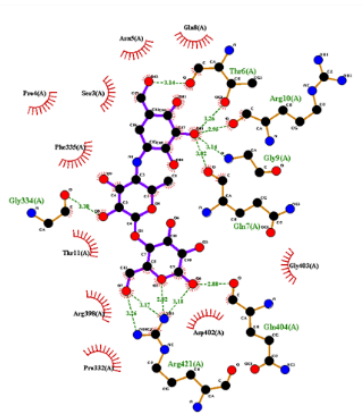

(c)

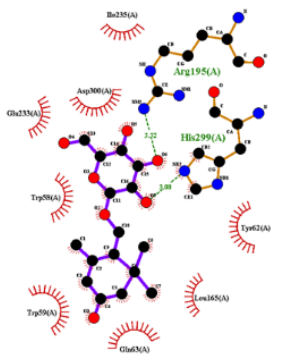

(f)

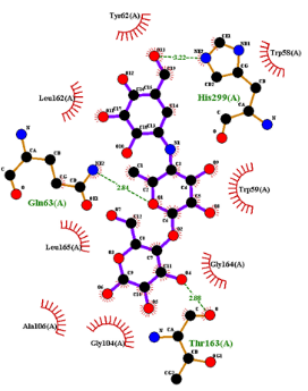

Figure 5. Molecular catalytic interaction of the compound identified from the methanolic extract (MeOH-E) of G. jasminoides with $\alpha$ amylase. Jasminoside $F(\mathbf{a})$, chlorogenic acid (b), jasminoside $\mathrm{A}(\mathbf{c})$, thymine (d), acarbose derived trisaccharide (e), and acarbose (f) interacting with diabetes-related enzyme of $\alpha$ amylase (5E0F).

\section{Molecular Interaction with $\alpha$-Glucosidase}

The in silico docking study revealed that jasminoside $\mathrm{F}$, jasminoside $\mathrm{B}$, chlorogenic acid and jasminoside A displayed a higher binding affinity with $\alpha$-glucosidase than other compounds studied in this study (Table 4; Figure 6). The interaction between jasminoside F and $\alpha$-glucosidase showed the binding affinity score of $-7.8 \mathrm{kcal} / \mathrm{mol}$ through the formation of five hydrogen bonds with amino acid residues such as Thr473, Asn476, Arg102 (Figure 6a). Jasminoside B established an interaction with $\alpha$-glucosidase via six hydrogen bonds interacting with amino acids residues (Arg102, Tyr104, Gly241, Arg103, Asn476) of $\alpha$-glucosidase with the binding affinity of $7.3 \mathrm{kcal} / \mathrm{mol}$ (Figure $6 \mathrm{~b}$ ). The chlorogenic acid exhibited the binding affinity score of $-8.2 \mathrm{kcal} / \mathrm{mol}$ with five hydrogen bond interactions with amino acid residues of Met269, Glu759, Val760, Tyr266 in $\alpha$-glucosidase (Figure $6 \mathrm{c}$ ). The molecular interaction between jasminoside $\mathrm{A}$ and $\alpha$-glucosidase exhibited a binding affinity of $7.8 \mathrm{kcal} / \mathrm{mol}$ by forming four hydrogen bonds with the amino acid residues Val760, Leu761, Glu762 (Figure 6d). However, the positive controls such as acarbose-derived trisaccharide and acarbose showed the promising dock binding affinity of $8.7 \mathrm{kcal} / \mathrm{mol}$ for interaction with $\alpha$-glucosidase (Table 4 ). The acarbose-derived trisaccharide was found to establish an interaction with $\alpha$-glucosidase through eight hydrogen bonds with amino acid residues of Trp39, Cys40, Ala13, Pro14, Asp11, Arg237, Trp179 (Figure 6e) while the acarbose established the interaction with $\alpha$-glucosidase through six hydrogen bonds with amino acid residues of Trp39, Cys40, Pro14, Ala13, Arg237, Asp11 (Figure 6f). Overall, the docking study revealed that interactions with $\alpha$-glucosidase of chlorogenic acid and jasminoside A were promising as compared to other compounds screened, and we hypothesize that these interactions might inhibit the activity of $\alpha$-glucosidase. This finds the support of earlier works on the antidiabetic and enzyme inhibitory activities of these compounds $[56,67,68]$. 

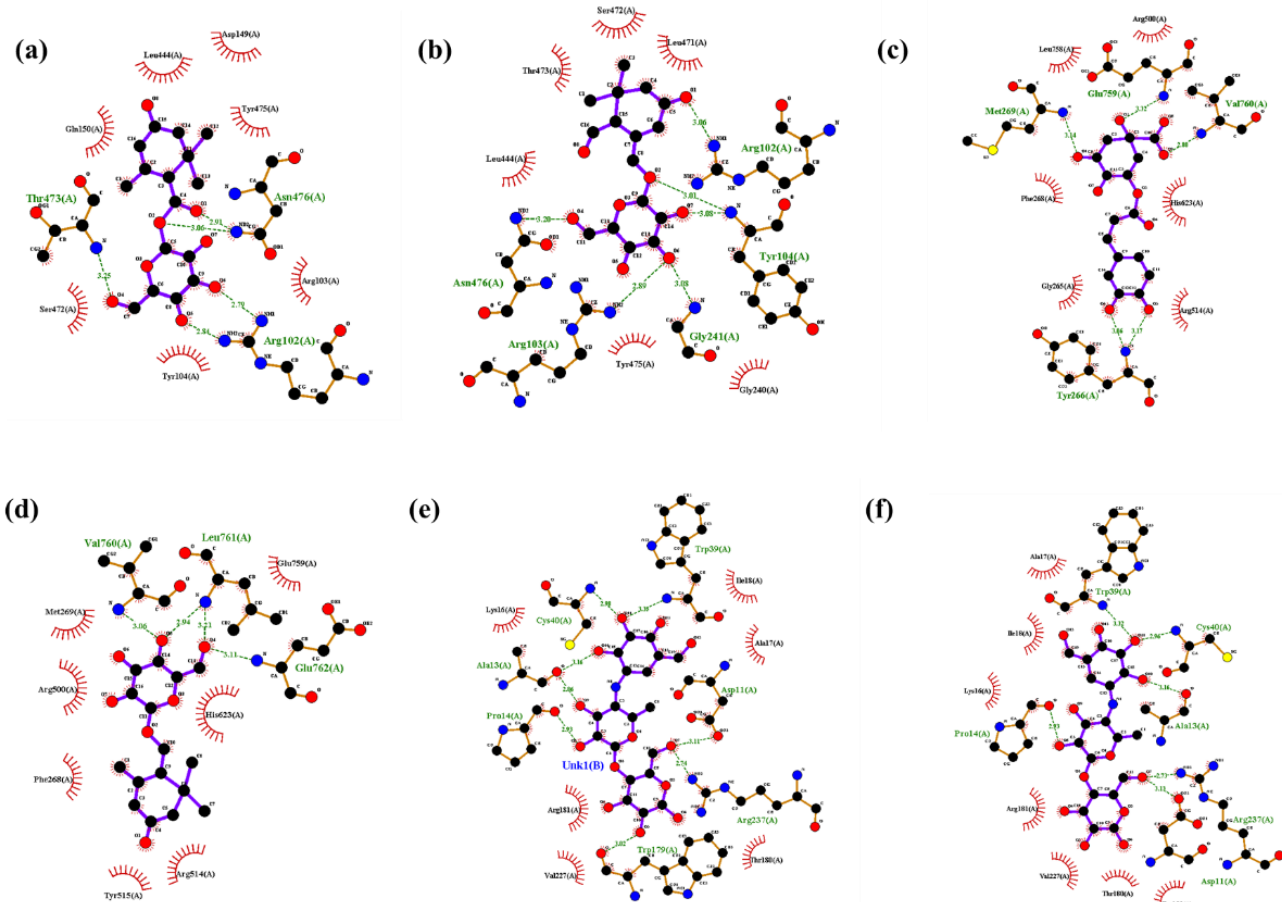

(e)

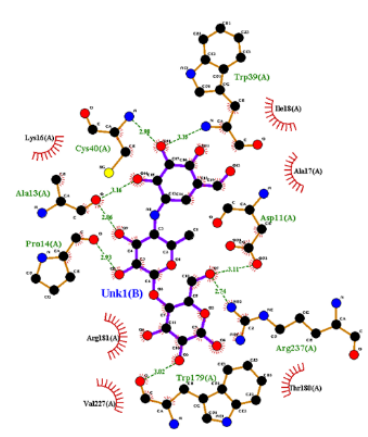

(f)

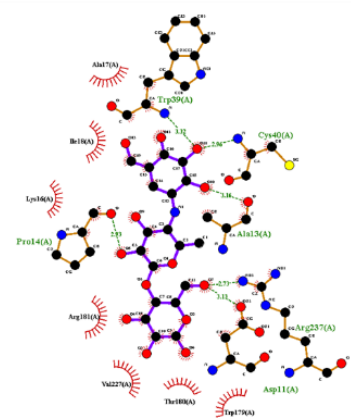

Figure 6. Molecular catalytic interaction of the compound identified from the methanolic extract (MeOH-E) of G. jasminoides with $\alpha$ glucosidase (5NN8). Jasminoside F (a), jasminoside B (b), chlorogenic acid (c), jasminoside A (d), acarbose derived trisaccharide (e), and acarbose (f) interacting with diabetes-related enzyme $\alpha$ glucosidase (5NN8).

\section{Materials and Methods}

\subsection{Chemicals, Cell Line, and Maintenance}

Ethidium bromide (EB), rhodamine 123 (Rh123), 2'-7' dichlorofluorescein diacetate (DCFH-DA), acridine orange (AO), 2,2'-azinobis (3-ethylbenzothiazoline-6-sulfonic acid) diammonium salt (ABTS), 1,2-diphenyl-1-picrylhydrazyl (DPPH), $\alpha$-glucosidase, and $\alpha$ amylase were purchased from Sigma-Aldrich (Seoul, Korea). The seed powder of G. jasminoides Ellis was procured from a local herbal company in South Korea, and authenticated by Professor M.H. Wang (Kangwon National University). Fetal bovine serum (FBS), penicillin and streptomycin, Dulbecco's Modified Eagle Medium (DMEM), Roswell Park Memorial Institute Medium (RPMI) were obtained from ThermoFisher Scientific (Seoul, Korea). The cytotoxicity assay kit (WST-CELLO MAX ${ }^{\mathrm{TM}}$ ) was purchased from MediFab (Seoul, Korea), while the cell line human hepatic HepG2 cells and mouse fibroblast NIH3T3 cells were received from Korean Cell Line Bank, (KCLB, Seoul, Korea).

\subsection{Preparation of Desiccative Ripe Fruits Extract}

One hundred gram of seed powder (desiccative ripe fruits) of the G. jasminoides was extracted with methanol (1:5 ratio) for $24 \mathrm{~h}$ agitation in a magnetic stirrer. The methanol extract (MeOH-E) was filtered through Whatman no 1 filter paper and then concentrated using a rotary evaporator at $40^{\circ} \mathrm{C}$. Besides the water extraction was done according to the protocols described earlier [23]. The yield of $\mathrm{MeOH}-\mathrm{E}$ and H2O-E was quantified using a weighing balance and then stored at $4{ }^{\circ} \mathrm{C}$ for further analytical experiments. The contents of total phenol and total flavonoids in $\mathrm{MeOH}-\mathrm{E}$ were measured according to methods described earlier [69-71].

\subsection{Antioxidant Activities}

$\mathrm{MeOH}-\mathrm{E}$ was analyzed for free radicals (DPPH and ABTS) scavenging activity according to the protocols reported earlier [72,73]. For DPPH inhibition assay, $100 \mu \mathrm{L}$ of $\mathrm{MeOH}-\mathrm{E}$ $(1.95-1000 \mu \mathrm{g} / \mathrm{mL})$ and $100 \mu \mathrm{L}$ of $\mathrm{DPPH}(100 \mu \mathrm{M})$ were mixed and incubated at $27^{\circ} \mathrm{C}$ for 
$10 \mathrm{~min}$. Later the reaction mixture was observed at $517 \mathrm{~nm}$ using a UV spectrophotometer. The percentage of the DPPH scavenging was determined by adopting the formula reported earlier [74]. For the ABTS inhibition assay, firstly, the oxidative form of the $\mathrm{ABTS}^{+}$was generated by mixing the potassium persulfate $(2.45 \mathrm{~mm})$ and ABTS $(7 \mathrm{~mm})$ at the ratio of the $0.5: 1$ ratio in dark conditions at $27^{\circ} \mathrm{C}$ for $24 \mathrm{~h}$. For the reaction, the $100 \mu \mathrm{L}$ of $\mathrm{ABTS}^{+}$ and $100 \mu \mathrm{L}$ of MeOH-E $(1.95-1000 \mu \mathrm{g} / \mathrm{mL})$ were mixed and incubated at $27^{\circ} \mathrm{C}$ for $10 \mathrm{~min}$. Afterward, the reaction mixture was measured at $734 \mathrm{~nm}$ using a UV spectrophotometer. The percentage of ABTS scavenging $=(($ Control-sample $) /$ control $) \times 100)$. The control is ABTS+solution alone.

\subsection{Enzyme Inhibition Activities}

The inhibition of $\alpha$-glucosidase and $\alpha$-amylase was measured according to previously reported methods [75-77]. Acarbose was used as a positive control for this experiment. For the $\alpha$-glucosidase inhibition assay, $50 \mu \mathrm{L}$ of MeOH-E $(1.95-1000 \mu \mathrm{g} / \mathrm{mL})$ was added to $20 \mu \mathrm{L}$ of $\alpha$-glucosidase ( $1 \mathrm{U}$ ) and this, $25 \mu \mathrm{L}$ of $p$-nitrophenyl glucopyranoside (pNPG; $5 \mathrm{M}$ ) was added and incubated at $37^{\circ} \mathrm{C}$ for $30 \mathrm{~min}$. Later, the $100 \mu \mathrm{L}$ of $\mathrm{Na}_{2} \mathrm{CO}_{3}(0.1 \mathrm{M})$ was added to stop the reaction and measured at $405 \mathrm{~nm}$ using a UV spectrophotometer. For the $\alpha$-amylase inhibition assay, $50 \mu \mathrm{L}$ of MeOH-E (1.95-1000 $\mu \mathrm{g} / \mathrm{mL}), 150 \mu \mathrm{L}$ of starch $(0.5 \%)$, $10 \mu \mathrm{L}$ of $\alpha$-amylase ( $2 \mathrm{U}$ ) were mixed and incubated at $37^{\circ} \mathrm{C}$ for $30 \mathrm{~min}$. Later $20 \mu \mathrm{L}$ of $\mathrm{NaOH}(2 \mathrm{M})$ was added to stop the reaction. Then $20 \mu \mathrm{L}$ DNS of (3,5-dinitrosalicylic acid) was added to the reaction solution and boiled for $20 \mathrm{~min}$ at $100{ }^{\circ} \mathrm{C}$. Finally, the reaction mixture was cooled at room temperature and read at $540 \mathrm{~nm}$ using a UV spectrophotometer. The percentage of enzyme inhibition was determined by following the formula reported elsewhere [74].

\subsection{Cell Culture Experiments}

\subsubsection{Cytotoxicity}

The cytotoxicity of MeOH-E was tested in the normal NIH3T3 cells and HepG2 cells $\left(1 \times 10^{4}\right.$ cells/well) cultured in DMEM composed of FBS (10\%), antibiotic solution (1\%) for $24 \mathrm{~h}$ at $37{ }^{\circ} \mathrm{C}$ in $5 \%$ of a $\mathrm{CO}_{2}$ incubator. Later, the cells were treated with $\mathrm{MeOH}-\mathrm{E}$ $(0-100 \mu \mathrm{g} / \mathrm{mL})$ for $24 \mathrm{~h}$. After the treatment period, WST reagent $(10 \mu \mathrm{L})$ was added, kept in a $\mathrm{CO}_{2}$ incubator for $1 \mathrm{~h}$, and then OD was measured at $450 \mathrm{~nm}$ using UV spectrophotometer (SpectraMax ${ }^{\circledR}$ Plus Microplate Reader, Molecular Devices, San Jose, CA, USA). The percentage of cell toxicity was calculated by adopting the formula reported previously [78].

\subsubsection{Determination of Glucose Uptake}

To assess the MeOH-E induced glucose uptake in the HepG2 cells, an insulin-resistant model cell line (IR-HepG2) was firstly generated according to the protocol reported elsewhere $[79,80]$. The well-established IR-HepG2 cells $\left(1 \times 10^{4}\right.$ cells/well $)$ were cultured in high glucose DMEM incorporated with FBS (10\%) and antibiotic solution (1\%) in a $5 \% \mathrm{CO}_{2}$ incubator for $24 \mathrm{~h}$. For the treatment, various concentrations of MeOH-E $(0-100 \mu \mathrm{g} / \mathrm{mL})$ were added to cells and incubated for $24 \mathrm{~h}$ in the above-mentioned conditions. Besides, the positive control (HepG2) cells were maintained. After the incubation, the cells including the culture media were harvested and centrifuged at $440 \mathrm{~g}$ for $5 \mathrm{~min}$, and the supernatant was used for glucose assay by DNS method. Glucose uptake (\%) was estimated using the formula:(OD of high glucose DMEM media-IR-HepG2 cultured supernatant OD)/OD of high glucose DMEM media) $\times 100$. Followed by the prevention of oxidative stress, mitochondrial membrane loss, and nucleus damage in IR-HepG2 by treatment of MeOH-E was observed using various staining assay as reported in earlier studies [81-83].

\subsection{UHPLC-QTOF-MS/MS Analysis}

For the UHPLC-QTOF-MS/MS analysis, MeOH-E was dissolved in 70\% methanol, filtered with PTFE syringe filter $(0.2 \mu \mathrm{m})$, and finalized in $20 \mathrm{ppm}$ of MeOH-E. The LC/MS systems consisted of a Waters Acquity UPLC I-Class system (Waters Corp., Milford, MA, 
USA) coupled to Waters Xevo G2 QTOF mass spectrometer (Waters MS Technologies, Manchester, UK) equipped with an electrospray ionization (ESI) interface. The chromatographic separation was done with LC/MS equipped Waters Acquity UPLC BEH C18 $(150 \mathrm{~mm} \times 2.1 \mathrm{~mm}, 1.7 \mu \mathrm{m})$ (Waters Corp.). For the UHPLC, $2 \mu \mathrm{L}$ of the sample was injected with a flow rate of $300 \mu \mathrm{L} / \mathrm{min}$ with a temperature of auto-sampler $\left(10^{\circ} \mathrm{C}\right)$ and column oven $\left(40^{\circ} \mathrm{C}\right)$. The mobile phases were $0.1 \%$ formic acid in $\mathrm{H}_{2} \mathrm{O}(\mathrm{A})$ and $0.1 \%$ formic acid in acetonitrile (B), and the following gradient was used: $10-90 \%$ B (0-12 min) and $100 \%$ B (12.1-16.0 $\mathrm{min})$. The MS/MS data were obtained using a collision energy ramp from 15 to $45 \mathrm{eV}$ in $\mathrm{MS}^{\mathrm{E}}$ mode. The ESI parameters were set as follows: in negative ion mode in Continuum format, a capillary voltage of $2.5 \mathrm{kV}$, cone voltage of $45 \mathrm{~V}$, source temperature of $120^{\circ} \mathrm{C}$, desolvation temperature of $350{ }^{\circ} \mathrm{C}$, cone gas flow of $50 \mathrm{~L} / \mathrm{h}$, and desolvation gas flow of $800 \mathrm{~L} / \mathrm{h}$. The ion acquisition rate was $0.25 \mathrm{~s}$ with the mass range from $m / z 100$ to 1600 . The instrument was calibrated using a sodium formate solution as the calibration standard. Leucine enkephalin $(m / z 554.2615$ in negative mode) was used as the reference lock mass at a concentration of $200 \mathrm{pg} / \mu \mathrm{L}$ and a flow rate of $5 \mu \mathrm{L} / \mathrm{min}$ and was sprayed into the MS instrument every $10 \mathrm{~s}$ to ensure accuracy and reproducibility. The data acquisition was measured by MassLynx V4.1 (Waters Corp.). The compounds were identified using the in-house phytochemical library (UNIFI 1.8; Waters Corp.) [40,41].

\subsection{Gas Chromatography Analysis}

The organic compounds present in $\mathrm{MeOH}-\mathrm{E}$ was determined using a gas chromatography (Agilent 789A, Agilent, Santa Clara, CA, USA) mass spectrophotometry (Agilent 5975C; GC-MSD) system in the scan range of $m / z 50-500$ according to the detailed operation conditions described elsewhere [64,84]. The GS-MS used in this study was equipped with DB-5MS ( $30 \mathrm{~m}$ length $\times 0.25 \mathrm{~mm}$ inner diameter $\times 0.25 \mu \mathrm{m}$ thickness of film) column and performed under operation condition as the flow rate of $1 \mathrm{~mL} / \mathrm{min}$, injection mode (5:1) with an inlet temperature of $250^{\circ} \mathrm{C}$, interface temperature of $280^{\circ} \mathrm{C}$, ion source of EI, $70 \mathrm{eV}$, with the temperature of $280^{\circ} \mathrm{C}$. The compounds present in the MeOH-E were tentatively identified by matching the GC-MS data with the electronic library of W8N05ST.L.

\subsection{Molecular Docking}

The compounds with enzyme inhibitory activity identified from MeOH-E were virtually analyzed against human lysosomal acid- $\alpha$-glucosidase (PDB: $5 N N 8$ ) and human pancreatic $\alpha$-amylase (PDB: 5E0F) by molecular docking. The structure files of ligands were prepared using ChemBioDraw 15.0 (PerkinElmer, Waltham, MA, USA) and then saved as mol. These mol files of ligands were used for energy minimization according to the principle of gasteiger [85]. The 3D structure of PDB of 5NN8 and 5E0F were retrieved from RSCB (https: / /www.rcsb.org/) and before the docking experiment the water residue was removed and the binding packet size was prepared as reported earlier [12]. Finally, the molecular docking between various ligand and targeted protein was carried out using Autodock Vina 1.1.2. Finally, the interactions between the protein and compounds were observed using LIGPLOT+(v.2.2).

\subsection{Statistical Analysis}

All the experiments were executed in triplicate and the results are presented with mean \pm standard error (SE). The descriptive statistics, student ' $t$ ' test, and analysis of various (ANOVA), line diagrams, Duncan's multiple range test (DMRT) were made using excel. 2010 and SPSS (Ver 2016, IBM, Armonk, NY, USA). The difference at $p<0.05$ was considered as significant among the factors.

\section{Conclusions}

In summary, this work analyzed the enzyme inhibition, anti-diabetic activities and metabolites present in the MeOH-E of G. jasminoides by using LC-MS/MS and GC-MS. The MeOH-E showed higher enzyme inhibition, antioxidant and anti-diabetic activities in 
IR-HepG2 cells. Metabolic profiling studies tentatively identified a total of 54 compounds including iridoids, terpenoids, fatty acid, phenolic acid derivatives from $\mathrm{MeOH}-\mathrm{E}$ of G. jasminoides based on the observed $m / z$ molecular ions in LC-MS/MS and GC-MS. The compounds identified were nine iridoid glycosides, 13 monoterpenoides, two each of flavonoids and carotenoids. Among the compounds identified chlorogenic acid and jasminoside A were found promising in interacting with $\alpha$-glucosidase and $\alpha$-amylase, as evidenced by molecular docking studies. Therefore, the present work concluded that bioactivity of the MeOH-E of G. jasminoides was the synergistic effect of various compounds present in the extract. According to the molecular screening, it is recommended that chlorogenic acid and jasminoside A be considered as candidate molecules for anti-diabetic activity. However, further studies are required for the purification and characterization of these two molecules and to determine their molecular mechanism of anti-diabetic activity for the development of future therapeutics.

Supplementary Materials: The following are available online at https://www.mdpi.com/1424-824 7/14/2/102/s1, Supplementary Figure S1. TIC chromatogram of metabolites profiling of methanolic extract (MeOH-E) of G. jasminoides by UHPLC-ESI-qTOF-MS/MS analysis. (a) Overall TIC chromatogram of MeOH-E of retention time (14 min) and (b) magnification of the TIC chromatogram from 1-5 min of retention time. Supplementary Figure S2. Low molecular weight and alkaloids identified from the methanolic extract(MeOH-E) of G. jasminoides by GCMS. Supplementary Table S1. GC-MS based analysis of alkaloids and low molecular weight molecules from methanolic extract (MeOH-E) of G. jasminoides. Supplementary Table S2. Assessment of the Drug-likeness through Lipinski's strategies for methanolic extract (MeOH-E) of G. jasminoides by web tool (SwissADME).

Author Contributions: K.S.: Conceptualization, Formal analysis, Investigation, Methodology, Software, Writing - original draft, Writing—review \& editing. S.P.: Investigation, Methodology, Validation, Writing — review \& editing. A.S.: Methodology, Validation, Data curation. K.-N.K.: Formal analysis, Validation, S.-H.C.: Formal analysis, Validation, A.V.A.M.: Data curation, Validation. M.-H.W.: Funding acquisition, Project administration, Supervision, Writing—review \& editing. All authors have read and agreed to the published version of the manuscript.

Funding: This work was supported by Korea Research Fellowship Program through the National Research Foundation of Korea (NRF) funded by the Ministry of Science, ICT and Future Planning (2017H1D3A1A01052610) and National Research Foundation of Korea (2019R1A1055452).

Institutional Review Board Statement: Not Applicable.

Informed Consent Statement: Not Applicable.

Data Availability Statement: The data presented in this study are available on request.

Conflicts of Interest: The authors declare no conflict of interest.

\section{References}

1. Saeedi, P.; Petersohn, I.; Salpea, P.; Malanda, B.; Karuranga, S.; Unwin, N.; Colagiuri, S.; Guariguata, L.; Motala, A.A.; Ogurtsova, K.; et al. Global and regional diabetes prevalence estimates for 2019 and projections for 2030 and 2045: Results from the International Diabetes Federation Diabetes Atlas, 9th edition. Diabetes Res. Clin. Pract. 2019, 157, 107843. [CrossRef] [PubMed]

2. Behl, T.; Kotwani, A. Anti-hyperglycemic effect of Terminalia catappa fruit extract in streptozotocin-induced diabetic rats. Int. J. Pharm. Pharm. Sci. 2017, 9, 212. [CrossRef]

3. Apoorva, S.M.; Sridhar, N.; Suchetha, A. Prevalence and severity of periodontal disease in type 2 diabetes mellitus (non-insulindependent diabetes mellitus) patients in Bangalore city: An epidemiological study. J. Indian Soc. Periodontol. 2013, 17, 25-29. [CrossRef] [PubMed]

4. Ram Niwas, J.; Gyan Chand, J. Evaluation of Antidiabetic Activity of Hydroalcoholic Extract of Cassia fistula Linn. pod in Streptozotocin-Induced Diabetic Rats. Pharmacogn. J. 2017, 9, 599-606.

5. Fargion, S.; Dongiovanni, P.; Guzzo, A.; Colombo, S.; Valenti, L.; Fracanzani, A.L. Iron and insulin resistance. Aliment. Pharmacol. Ther. 2005, 22, 61-63. [CrossRef]

6. Teng, H.; Yuan, B.; Gothai, S.; Arulselvan, P.; Song, X.; Chen, L. Dietary triterpenes in the treatment of type 2 diabetes: To date. Trends Food Sci. Technol. 2018, 72, 34-44. [CrossRef]

7. Cade, W.T. Diabetes-Related Microvascular and Macrovascular Diseases in the Physical Therapy Setting. Phys. Ther. 2008, 88, 1322-1335. [CrossRef] 
8. Chawla, R.; Chawla, A.; Jaggi, S. Microvasular and macrovascular complications in diabetes mellitus: Distinct or continuum? Indian J. Endocrinol. Metab. 2016, 20, 546-551. [CrossRef]

9. Yu, Z.; Yin, Y.; Zhao, W.; Liu, J.; Chen, F. Anti-diabetic activity peptides from albumin against $\alpha$-glucosidase and $\alpha$-amylase. Food Chem. 2012, 135, 2078-2085. [CrossRef]

10. Khanal, P.; Patil, B.M. $\alpha$-Glucosidase inhibitors from Duranta repens modulate 553 signaling pathway in diabetes mellitus. Adv. Tradit. Med. 2020, 20,1-12. [CrossRef]

11. Wang, P.-C.; Zhao, S.; Yang, B.-Y.; Wang, Q.; Kuang, H. Anti-diabetic polysaccharides from natural sources: A review. Carbohydr. Polym. 2016, 148, 86-97. [CrossRef] [PubMed]

12. Aispuro-Pérez, A.; López-Ávalos, J.; García-Páez, F.; Montes-Avila, J.; Picos-Corrales, L.A.; Ochoa-Terán, A.; Bastidas, P.; Montaño, S.; Calderón-Zamora, L.; Osuna-Martínez, U.; et al. Synthesis and molecular docking studies of imines as $\alpha$-glucosidase and $\alpha$-amylase inhibitors. Bioorganic Chem. 2020, 94, 103491. [CrossRef] [PubMed]

13. WHO. Global Report on Traditional and Complementary Medicine; WHO: Geneva, Switzerland, 2019; ISBN 978-92-4-151543-6.

14. Chen, L.; Li, M.; Yang, Z.; Tao, W.; Wang, P.; Tian, X.; Li, X.; Wang, W. Gardenia jasminoides Ellis: Ethnopharmacology, phytochemistry, and pharmacological and industrial applications of an important traditional Chinese medicine. J. Ethnopharmacol. 2020, 257, 112829. [CrossRef] [PubMed]

15. Wang, L.; Yang, C.; Song, F.; Liu, Z.; Liu, S. The therapeutic effectiveness of Gardenia jasminoides on type 2 diabetes rats: Mass spectrometry-based metabolomics approach. J. Agric. Food Chem. 2020, 68, 9673-9682. [CrossRef] [PubMed]

16. Stasiak, N.; Kukuła-Koch, W.; Głowniak, K. Modern industrial and pharmacological applications of indigo dye and its derivatives-A review. Acta Pol. Pharm. Drug Res. 2014, 71, 215-221.

17. Xiao, W.; Li, S.; Wang, S.; Ho, C.-T. Chemistry and bioactivity of Gardenia jasminoides. J. Food Drug Anal. 2017, 25, 43-61. [CrossRef]

18. Chen, J.-L.; Shi, B.-Y.; Xiang, H.; Hou, W.-J.; Qin, X.-M.; Tian, J.-S.; Du, G. 1H nmR-based metabolic profiling of liver in chronic unpredictable mild stress rats with genipin treatment. J. Pharm. Biomed. Anal. 2015, 115, 150-158. [CrossRef]

19. Wang, G.-F.; Wu, S.-Y.; Xu, W.; Jin, H.; Zhu, Z.-G.; Li, Z.-H.; Tian, Y.; Zhang, J.-J.; Rao, J.-J.; Wu, S.-G. Geniposide inhibits high glucose-induced cell adhesion through the NF-кB signaling pathway in human umbilical vein endothelial cells. Acta Pharmacol. Sin. 2010, 31, 953-962. [CrossRef]

20. Pham, T.Q.; Cormier, F.; Farnworth, E.; Tong, A.V.H.; Van Calsteren, M.-R. Antioxidant Properties of Crocin from Gardenia jasminoides Ellis and Study of the Reactions of Crocin with Linoleic Acid and Crocin with Oxygen. J. Agric. Food Chem. 2000, 48, 1455-1461. [CrossRef]

21. Higashino, S.; Sasaki, Y.; Giddings, J.C.; Hyodo, K.; Sakata, S.F.; Matsuda, K.; Horikawa, Y.; Yamamoto, J. Crocetin, a Carotenoid from Gardenia jasminoides Ellis, Protects against Hypertension and Cerebral Thrombogenesis in Stroke-prone Spontaneously Hypertensive Rats. Phytother. Res. 2014, 28, 1315-1319. [CrossRef]

22. Dorman, H.; Peltoketo, A.; Hiltunen, R.; Tikkanen, M. Characterisation of the antioxidant properties of de-odourised aqueous extracts from selected Lamiaceae herbs. Food Chem. 2003, 83, 255-262. [CrossRef]

23. Juma, B.F.; Majinda, R.R.T. Constituents of Gardenia volkensii: Their brine shrimp lethality and DPPH radical scavenging properties. Nat. Prod. Res. 2007, 21, 121-125. [CrossRef] [PubMed]

24. Debnath, T.; Park, P.-J.; Nath, N.C.D.; Samad, N.B.; Park, H.W.; Lim, B. Antioxidant activity of Gardenia jasminoides Ellis fruit extracts. Food Chem. 2011, 128, 697-703. [CrossRef]

25. Sayd, S.S.; Hanan, A.A.; Taie, H.A.A.; Taha, L.S. Micropropagation, antioxidant activity, total phenolics and flavonoids con-tent of Gardenia jasminoides Ellis as affected by growth regulators. Int. J. Acad. Res. 2010, 2, 184-191.

26. Gowd, V.; Bao, T.; Wang, L.; Huang, Y.; Chen, S.; Zheng, X.; Cui, S.; Chen, W. Antioxidant and antidiabetic activity of blackberry after gastrointestinal digestion and human gut microbiota fermentation. Food Chem. 2018, 269, 618-627. [CrossRef]

27. Hua, D.; Luo, W.; Duan, J.; Jin, D.; Zhou, X.; Sun, C.; Wang, Q.; Shi, C.; Jiang, Z.; Wang, R.; et al. Screening and identification of potent $\alpha$-glycosidase inhibitors from Gardenia jasminoides Ellis. S. Afr. J. Bot. 2018, 119, 377-382. [CrossRef]

28. Saravana, P.S.; Cho, Y.-N.; Patil, M.P.; Cho, Y.-J.; Kim, G.-D.; Park, Y.B.; Woo, H.-C.; Chun, B.-S. Hydrothermal degradation of seaweed polysaccharide: Characterization and biological activities. Food Chem. 2018, 268, 179-187. [CrossRef]

29. Hao, S.; Wang, J.; Li, S.; Shang, F.; Qin, Y.; Wu, T.; Bao, X.; Cao, Q.; Wang, C.; Sun, B. Preparation of Gardenia red pigment and its antineoplastic activity in multiple tumor cells. Food Biosci. 2020, 35, 100582. [CrossRef]

30. Moritome, N.; Kishi, Y.; Fujii, S. Properties of red pigments prepared from geniposidic acid and amino acids. J. Sci. Food Agric. 1999, 79, 810-814. [CrossRef]

31. Saravanakumar, K.; Chelliah, R.; Shanmugam, S.; Varukattu, N.B.; Oh, D.-H.; Kathiresan, K.; Wang, M.-H. Green synthesis and characterization of biologically active nanosilver from seed extract of Gardenia jasminoides Ellis. J. Photochem. Photobiol. B Biol. 2018, 185, 126-135. [CrossRef]

32. Wu, X.; Liu, K.; Liu, P.-C.; Liu, R. Dual AO/EB Staining to Detect Apoptosis in Osteosarcoma Cells Compared with Flow Cytometry. Med. Sci. Monit. Basic Res. 2015, 21, 15-20. [CrossRef] [PubMed]

33. Zhang, Q.; Hu, X.-F.; Xin, M.-M.; Liu, H.-B.; Sun, L.; Morris-Natschke, S.L.; Chen, Y.; Lee, K.-H. Antidiabetic potential of the ethyl acetate extract of Physalis alkekengi and chemical constituents identified by HPLC-ESI-QTOF-MS. J. Ethnopharmacol. 2018, 225, 202-210. [CrossRef] [PubMed]

34. Shao, J.; Xue, J.; Dai, Y.; Liu, H.; Chen, N.; Jia, L.; Huang, J. Inhibition of human hepatocellular carcinoma HepG2 by phthalocyanine photosensitiser PHOTOCYANINE: ROS production, apoptosis, cell cycle arrest. Eur. J. Cancer 2012, 48, 2086-2096. [CrossRef] 
35. Ando, T.; Nagumo, M.; Ninomiya, M.; Tanaka, K.; Linhardt, R.J.; Koketsu, M. Synthesis of coumarin derivatives and their cytoprotective effects on $\mathrm{t}$-BHP-induced oxidative damage in HepG2 cells. Bioorganic Med. Chem. Lett. 2018, 28, $2422-2425$. [CrossRef] [PubMed]

36. Song, G.; Sun, Y.; Liu, Y.; Wang, X.; Chen, M.; Miao, F.; Zhang, W.; Yu, X.; Jin, J. Low molecular weight fluorescent probes with good photostability for imaging RNA-rich nucleolus and RNA in cytoplasm in living cells. Biomaterials 2014, 35, 2103-2112. [CrossRef]

37. Zhang, L.; Mizumoto, K.; Sato, N.; Ogawa, T.; Kusumoto, M.; Niiyama, H.; Tanaka, M. Quantitative determination of apoptotic death in cultured human pancreatic cancer cells by propidium iodide and digitonin. Cancer Lett. 1999, 142, 129-137. [CrossRef]

38. El Sayed, A.M.; Basam, S.M.; El-Naggar, E.-M.B.A.; Marzouk, H.S.; El-Hawary, S. LC-MS/MS and GC-MS profiling as well as the antimicrobial effect of leaves of selected Yucca species introduced to Egypt. Sci. Rep. 2020, 10, 1-15. [CrossRef]

39. Kivilompolo, M.; Obůrka, V.; Hyötyläinen, T. Comparison of GC-MS and LC-MS methods for the analysis of antioxidant phenolic acids in herbs. Anal. Bioanal. Chem. 2007, 388, 881-887. [CrossRef]

40. Yang, Z.-R.; Wang, Z.-H.; Tang, J.-F.; Yan, Y.; Yue, S.-J.; Feng, W.-W.; Shi, Z.-Y.; Meng, X.-T.; Peng, C.; Wang, C.-Y.; et al. UPLCQTOF/MSE and Bioassay Are Available Approaches for Identifying Quality Fluctuation of Xueshuantong Lyophilized Powder in Clinic. Front. Pharmacol. 2018, 9, 633. [CrossRef]

41. Jeong, M.S.; Park, S.; Han, E.J.; Park, S.Y.; Kim, M.J.; Jung, K.; Cho, S.-H.; Kim, S.-Y.; Yoon, W.-J.; Ahn, G.; et al. Pinus thunbergii PARL leaf protects against alcohol-induced liver disease by enhancing antioxidant defense mechanism in BALB/c mice. J. Funct. Foods 2020, 73, 104116. [CrossRef]

42. Fu, Z.; Ling, Y.; Li, Z.; Chen, M.; Sun, Z.; Huang, C. HPLC-Q-TOF-MS/MS for analysis of major chemical constituents of Yinchen-Zhizi herb pair extract. Biomed. Chromatogr. 2014, 28, 475-485. [CrossRef] [PubMed]

43. Hussain, H.; Green, I.R.; Saleem, M.; Raza, M.L.; Nazir, M. Therapeutic Potential of Iridoid Derivatives: Patent Review. Inventions 2019, 4, 29. [CrossRef]

44. Jia, J.; Liu, M.; Wen, Q.; He, M.; Ouyang, H.; Chen, L.; Li, J.; Feng, Y.; Zhong, G.; Yang, S. Screening of anti-complement active ingredients from Eucommia ulmoides Oliv. branches and their metabolism in vivo based on UHPLC-Q-TOF/MS/MS. J. Chromatogr. B 2019, 1124, 26-36. [CrossRef] [PubMed]

45. Zhang, S.; Li, Y.; Zhang, C.-X.; Huang, W.-Z.; Ding, G.; Xiao, W.; Bi, Y.-A.; Xiao, W. Research on the change of chemical composition in productive process of Re Du Ning Injections by HPLC/Q-TOF MS. Biomed. Chromatogr. 2015, 30, 131-141. [CrossRef] [PubMed]

46. Wu, H.; Li, X.; Yan, X.; An, L.; Luo, K.; Shao, M.; Jiang, Y.; Xie, R.; Feng, F. An untargeted metabolomics-driven approach based on LC-TOF/MS and LC-MS/MS for the screening of xenobiotics and metabolites of Zhi-Zi-Da-Huang decoction in rat plasma. J. Pharm. Biomed. Anal. 2015, 115, 315-322. [CrossRef] [PubMed]

47. Wang, L.; Liu, S.; Xing, J.; Liu, Z.; Song, F. Characterization of interaction property of multi-components in Gardenia jasminoides with aldose reductase by microdialysis combined with liquid chromatography coupled to mass spectrometry. Rapid Commun. Mass Spectrom. 2016, 30, 87-94. [CrossRef] [PubMed]

48. Wang, L.; Liu, S.; Zhang, X.; Xing, J.; Liu, Z.; Song, F. A strategy for identification and structural characterization of compounds from Gardenia jasminoides by integrating macroporous resin column chromatography and liquid chromatography-tandem mass spectrometry combined with ion-mobility spectrometry. J. Chromatogr. A 2016, 1452, 47-57. [CrossRef] [PubMed]

49. Feng, W.; Dong, Q.; Liu, M.; Li, S.; Liu, T.; Wang, X.-G.; Niu, L.-Y. Screening and identification of multiple constituents and their metabolites of Zhi-zi-chi decoction in rat urine and bile by ultra-high-performance liquid chromatography quadrupole time-of-flight mass spectrometry. Biomed. Chromatogr. 2017, 31, e3978. [CrossRef]

50. Wang, S.-C.; Tseng, T.-Y.; Huang, C.-M.; Tsai, T.-H. Gardenia herbal active constituents: Applicable separation procedures. J. Chromatogr. B 2004, 812, 193-202. [CrossRef]

51. He, W.; Liu, X.; Xu, H.; Gong, Y.; Yuan, F.; Gao, Y. On-line HPLC-ABTS screening and HPLC-DAD-MS/MS identification of free radical scavengers in Gardenia (Gardenia jasminoides Ellis) fruit extracts. Food Chem. 2010, 123, 521-528. [CrossRef]

52. Joo, Y.H.; Nam, M.H.; Chung, N.; Lee, Y.K. UPLC-QTOF-MS/MS screening and identification of bioactive compounds in fresh, aged, and browned Magnolia denudata flower extracts. Food Res. Int. 2020, 133, 109192. [CrossRef] [PubMed]

53. Wang, C.; Zhang, N.; Wang, Z.; Qi, Z.; Zhu, H.; Zheng, B.; Li, P.; Liu, J. Nontargeted Metabolomic Analysis of Four Different Parts of Platycodon grandiflorum Grown in Northeast China. Molecules 2017, 22, 1280. [CrossRef] [PubMed]

54. Liu, M.; He, M.; Gao, H.; Guo, S.; Jia, J.; Ouyang, H.; Feng, Y.; Yang, S. Strategy for rapid screening of antioxidant and antiinflammatory active ingredients in Gynura procumbens (Lour.) Merr. based on UHPLC-Q-TOF-MS/MS and characteristic ion filtration. Biomed. Chromatogr. 2019, 33, e4635. [CrossRef] [PubMed]

55. Breitmaier, E. Hemi- and Monoterpenes. In Terpenes: Flavors, Fragrances, Pharmaca, Pheromones; Wiley: Hoboken, NJ, USA, 2006; pp. 10-23. [CrossRef]

56. Chen, Q.C.; Youn, U.; Min, B.-S.; Bae, K. Pyronane Monoterpenoids from the Fruit of Gardenia jasminoides. J. Nat. Prod. 2008, 71, 995-999. [CrossRef]

57. Yu, Y.; Xie, Z.-L.; Gao, H.; Ma, W.-W.; Dai, Y.; Wang, Y.; Zhong, Y.; Yao, X.-S. Bioactive Iridoid Glucosides from the Fruit of Gardenia jasminoides. J. Nat. Prod. 2009, 72, 1459-1464. [CrossRef]

58. Akihisa, T.; Watanabe, K.; Yamamoto, A.; Zhang, J.; Matsumoto, M.; Fukatsu, M. Melanogenesis Inhibitory Activity of Monoterpene Glycosides from Gardeniae Fructus. Chem. Biodivers. 2012, 9, 1490-1499. [CrossRef] 
59. Peng, K.; Yang, L.; Zhao, S.; Chen, L.; Zhao, F.; Qiu, F. Chemical constituents from the fruit of Gardenia jasminoides and their inhibitory effects on nitric oxide production. Bioorganic Med. Chem. Lett. 2013, 23, 1127-1131. [CrossRef]

60. Machida, K.; Oyama, K.; Ishii, M.; Kakuda, R.; Yaoita, Y.; Kikuchi, M. Studies of the Constituents of Gardenia Species. II. Terpenoids from Gardeniae Fructus. Chem. Pharm. Bull. 2000, 48, 746-748. [CrossRef]

61. Chen, Y.; Yang, Z.L.; Zhang, L.H.; Liu, S.J.; Zhang, X.T. Determination of geniposide, crocin and crocetin in different pro-cessing products of fructus Gardeniae by HPLC-ELSD. J. Chin. Med. Mater. 2011, 34, 687-690.

62. Uekusa, Y.; Sugimoto, N.; Sato, K.; Yun, Y.S.; Kunugi, A.; Yamazaki, T.; Tanamoto, K.-I. Neocrocin A: A novel crocetin glycoside with a unique system for binding sugars isolated from Gardenia yellow. Chem. Pharm. Bull. 2007, 55, 1643-1646. [CrossRef]

63. Cai, L.; Li, R.; Tang, W.-J.; Meng, G.; Hu, X.-Y.; Wu, T.-N. Antidepressant-like effect of geniposide on chronic unpredictable mild stress-induced depressive rats by regulating the hypothalamus-pituitary-adrenal axis. Eur. Neuropsychopharmacol. 2015, 25, 1332-1341. [CrossRef] [PubMed]

64. Saravanakumar, K.; Chellia, R.; Hu, X.; Kathiresan, K.; Oh, D.-H.; Wang, M.-H. Eradication of Helicobacter pylori through the inhibition of urease and peptide deformylase: Computational and biological studies. Microb. Pathog. 2019, 128, 236-244. [CrossRef] [PubMed]

65. Chandrasekaran, M.; Senthilkumar, A.; Venkatesalu, V. Antibacterial and antifungal efficacy of fatty acid methyl esters from the leaves of Sesuvium portulacastrum L. Eur. Rev. Med. Pharmacol. Sci. 2011, 15, 775-780. [PubMed]

66. Lipinski, C.A. Lead- and drug-like compounds: The rule-of-five revolution. Drug Discov. Today Technol. 2004, 1, 337-341. [CrossRef] [PubMed]

67. Ali, N.; Rashid, S.; Nafees, S.; Hasan, S.K.; Shahid, A.; Majed, F.; Sultana, S. Protective effect of Chlorogenic acid against methotrexate induced oxidative stress, inflammation and apoptosis in rat liver: An experimental approach. Chem. Interact. 2017, 272, 80-91. [CrossRef]

68. Mccarty, M.F. A chlorogenic acid-induced increase in GLP-1 production may mediate the impact of heavy coffee consumption on diabetes risk. Med. Hypotheses 2005, 64, 848-853. [CrossRef]

69. Ardestani, A.; Yazdanparast, R. Inhibitory effects of ethyl acetate extract of Teucrium polium on in vitro protein glycoxidation. Food Chem. Toxicol. 2007, 45, 2402-2411. [CrossRef]

70. Zhishen, J.; Mengcheng, T.; Jianming, W. The determination of flavonoid contents in mulberry and their scavenging effects on superoxide radicals. Food Chem. 1999, 64, 555-559. [CrossRef]

71. Slinkard, L.; Singleton, V.L. Total phenol analyses: Automation and comparison with manual methods. Am. J. Enol. Vitic. 1977, $28,49-55$.

72. Blois, M.S. Antioxidant Determinations by the Use of a Stable Free Radical. Nature 1958, 181, 1199-1200. [CrossRef]

73. Cano, A.; Hernández-Ruíz, J.; García-Cánovas, F.; Acosta, M.; Arnao, M.B. An end-point method for estimation of the total antioxidant activity in plant material. Phytochem. Anal. 1998, 9, 196-202. [CrossRef]

74. Sathiyaseelan, A.; Saravanakumar, K.; Mariadoss, A.V.A.; Wang, M.-H. Biocompatible fungal chitosan encapsulated phytogenic silver nanoparticles enhanced antidiabetic, antioxidant and antibacterial activity. Int. J. Biol. Macromol. 2020, 153, 63-71. [CrossRef] [PubMed]

75. Kim, Y.-M.; Wang, M.-H.; Rhee, H.-I. A novel $\alpha$-glucosidase inhibitor from pine bark. Carbohydr. Res. 2004, 339, 715-717. [CrossRef] [PubMed]

76. Kandra, L.; Zajácz, Á.; Remenyik, J.; Gyémánt, G. Kinetic investigation of a new inhibitor for human salivary $\alpha$-amylase. Biochem. Biophys. Res. Commun. 2005, 334, 824-828. [CrossRef] [PubMed]

77. Saravanakumar, K.; Mariadoss, A.V.A.; Sathiyaseelan, A.; Wang, M.-H. Synthesis and characterization of nano-chitosan capped gold nanoparticles with multifunctional bioactive properties. Int. J. Biol. Macromol. 2020, 165, 747-757. [CrossRef] [PubMed]

78. Saravanakumar, K.; Vivek, R.; Boopathy, N.S.; Yaqian, L.; Kathiresan, K.; Chen, J. Anticancer potential of bioactive 16methylheptadecanoic acid methyl ester derived from marine Trichoderma. J. Appl. Biomed. 2015, 13, 199-212. [CrossRef]

79. Chen, L.; Teng, H.; Cao, H. Chlorogenic acid and caffeic acid from Sonchus oleraceus Linn synergistically attenuate insulin resistance and modulate glucose uptake in HepG2 cells. Food Chem. Toxicol. 2019, 127, 182-187. [CrossRef]

80. Teng, H.; Chen, L.; Song, H. The potential beneficial effects of phenolic compounds isolated from A. pilosa Ledeb on insulinresistant hepatic HepG2 cells. Food Funct. 2016, 7, 4400-4409. [CrossRef]

81. Saravanakumar, K.; Jeevithan, E.; Hu, X.; Chelliah, R.; Oh, D.-H.; Wang, M.-H. Enhanced anti-lung carcinoma and anti-biofilm activity of fungal molecules mediated biogenic zinc oxide nanoparticles conjugated with $\beta$-D-glucan from barley. J. Photochem. Photobiol. B Biol. 2020, 203, 111728. [CrossRef]

82. Saravanakumar, K.; Wang, M.-H. Biogenic silver embedded magnesium oxide nanoparticles induce the cytotoxicity in human prostate cancer cells. Adv. Powder Technol. 2019, 30, 786-794. [CrossRef]

83. Sakthivel, R.; Malar, D.S.; Devi, K.P. Phytol shows anti-angiogenic activity and induces apoptosis in A549 cells by depolarizing the mitochondrial membrane potential. Biomed. Pharmacother. 2018, 105, 742-752. [CrossRef] [PubMed]

84. Saravanan, M.; Senthilkumar, P.; Kalimuthu, K.; Chinnadurai, V.; Vasantharaj, S.; Ad, P. Phytochemical and pharmacological profiling of Turnera subulata Sm., a vital medicinal herb. Ind. Crop. Prod. 2018, 124, 822-833. [CrossRef]

85. Wang, J.; Wang, W.; Kollman, P.A.; Case, D.A. Automatic atom type and bond type perception in molecular mechanical calculations. J. Mol. Graph. Model. 2006, 25, 247-260. [CrossRef] [PubMed] 